\title{
An Son and the Neolithic of Southern Vietnam
}

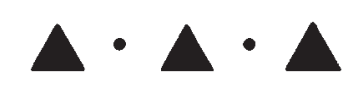

\author{
PETER BELLWOOD, MARC OXENHAM, BUI CHI HOANG, \\ NGUYEN KIM DZUNG, ANNA WILLIS, CARMEN SARJEANT, \\ PHILIP PIPER, HIROFUMI MATSUMURA, KATSUNORI TANAKA, \\ NANCY BEAVAN-ATHFIELD, THOMAS HIGHAM, NGUYEN QUOC \\ MANH, DANG NGOC KINH, NGUYEN KHANH TRUNG KIEN, \\ VO THANH HUONG, VAN NGOC BICH, TRAN THI KIM QUY, \\ NGUYEN PHUONG THAO, FREDELIZA CAMPOS, YO-ICHIRO SATO, \\ NGUYEN LAN CUONG AND NOEL AMANO
}

THE SITE OF AN SON

An Son (An Sơn in Vietnamese) is Situated on the edge of the active floodplain of the Vam Co Dong, a relatively small river that rises close to the Cambodian border and flows southward through Tay Ninh and Long An Provinces of southern Vietnam to meet the Vam Co Tay River (Fig. 1). It then flows jointly to the sea with the Vam Co Tay across the northern side of the Mekong Delta. In recent years, a large number of archaeological sites dating from the Neolithic to the Iron Age have been investigated in the two Vam Co drainage systems and the adjacent Dong Nai and Saigon River valleys, all forming the hinterland to modern Ho Chi Minh City. Many date from the Bronze and Iron Ages (1000 B.C.-A.D. 500), but the Vam Co Dong has a concentration of tested Neolithic sites dating from the late third and second millennia B.C., including An Son, with Loc Giang and Dong Canh Nong nearby, and Dinh Ong farther upstream in Tay Ninh Province (Nishimura 2002; Nishimura and Nguyen 2002).

Peter Bellwood, Marc Oxenham, Anna Willis, Carmen Sarjeant, Philip Piper and Fredeliza Campos are affiliated with the School of Archaeology and Anthropology, Australian National University, Canberra, Australia. Bui Chi Hoang, Nguyen Quoc Manh, Dang Ngoc Kinh, and Nguyen Khanh Trung Kien are affiliated with the Center for Archaeological Studies, Southern Institute of Sustainable Development, Ho Chi Minh City, Vietnam. Nguyen Kim Dzung, Vo Thanh Huong, and Nguyen Lan Cuong are affiliated with the Institute of Archaeology, Vietnam Academy of Social Sciences, Hanoi, Vietnam. Noel Amano is affiliated with the Archaeological Studies Program, University of the Philippines, Diliman, Quezon City, Philippines. Hirofumi Matsumura is affiliated with the Department of Anatomy, Sapporo Medical University, Japan. Katsunori Tanaka is affiliated with the Faculty of Humanities, Hirosaki University. Nancy Beavan-Athfield is affiliated with the Otago School of Medical Sciences, University of Otago, Dunedin, New Zealand. Thomas Higham is affiliated with the Oxford Radiocarbon Accelerator Unit, RLAHA, University of Oxford, United Kingdom. Van Ngoc Bich, Tran Thi Kim Quy, and Nguyen Phuong Thao are affiliated with the Long An Provincial Museum, Tan An City, Vietnam. Yo-Ichiro Sato is affiliated with the Research Institute of Humanity and Nature, Kyoto, Japan. 


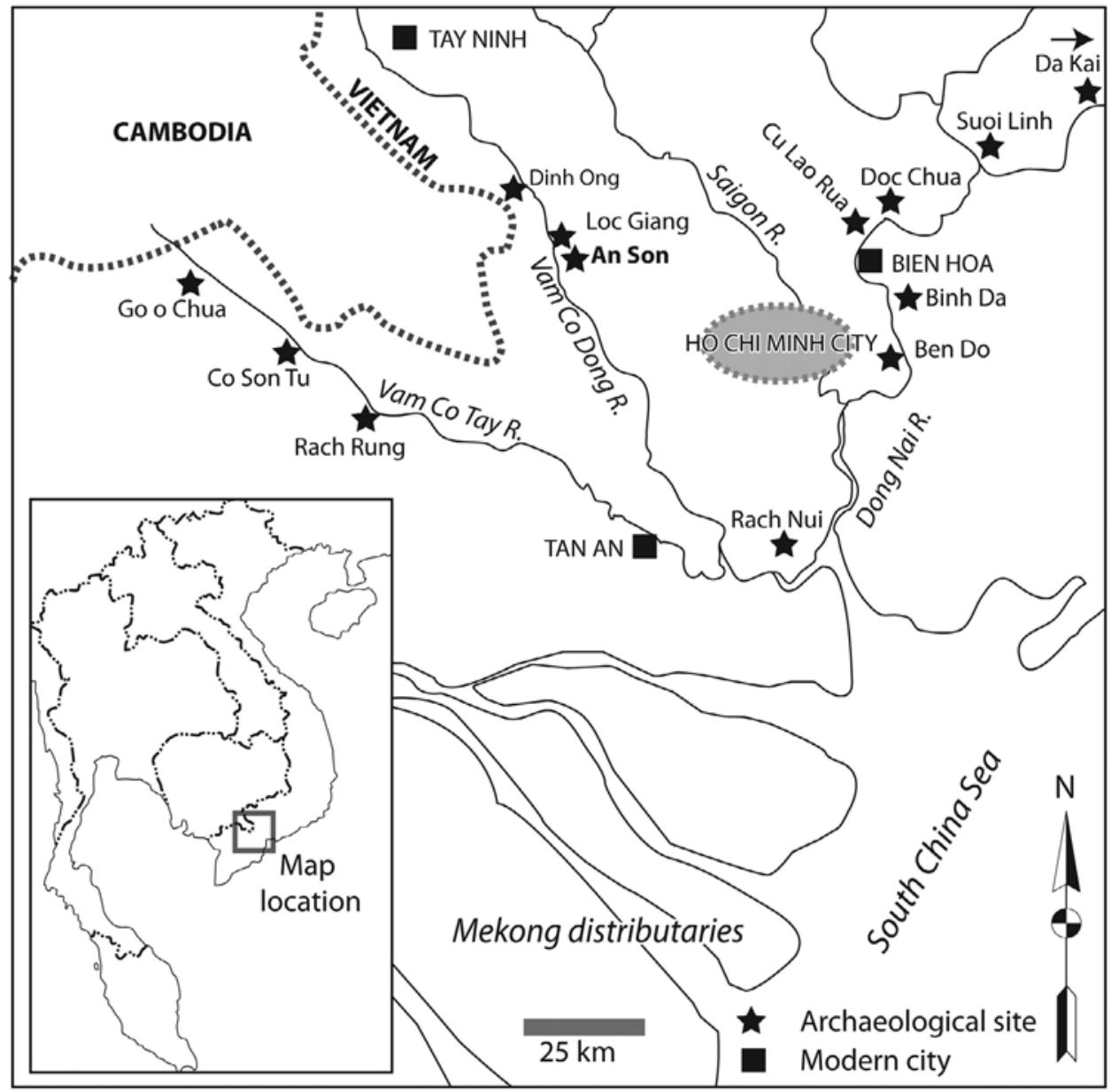

Fig. 1. The Mekong Delta region, and sites mentioned in the text.

An Son is located in An Ninh Tay commune, Duc Hoa District, close to the northern border of Long An Province, where the Vam Co Dong approaches close to a Cambodian border salient. The site is now about $75 \mathrm{~km}$ from the sea as the crow flies and lies about $300 \mathrm{~m}$ east of the Vam Co Dong River, on a slightly raised Quaternary alluvial terrace that flanks the modern active floodplain. It thus lies very close to the greater Mekong deltaic plain, in a location that was probably fairly close to the shoreline during the period of maximum Holocene marine transgression. Exactly when this transgression occurred is discussed by Nguyen et al. (2000), Ta et al. (2002), and Proske et al. (2010), who all favor a sea level high stand of +2.5 to $+4.5 \mathrm{~m}$ between 4000 and 3000 B.C. It is possible that the future site of An Son was under mangrove vegetation at this time, and very close to the contemporary shoreline. However, by the time the archaeological site was founded, between 2500 and 2000 B.C., the sea had already retreated and the shellfish from the site suggest lower riverine or upper 
estuarine conditions that could have been up to $10 \mathrm{~km}$ or more inland. The site itself contains no evidence for consumption of open shoreline marine foods.

An Son was initially reported in 1938 by Louis Malleret and Paul Levy (Malleret 1963:94-95), who collected a number of stone adzes from the surface and dug a $2 \mathrm{~m}$ deep sondage, finding decorated pottery and animal bones. A second location produced some bricks and a piece of worked sandstone, suggesting the possible former presence of Khmer architecture, presumably now beneath the modern temple building on top of the mound (Fig. 2). Today, the An Son mound rises to about $4 \mathrm{~m}$ above the natural alluvium on which the site is founded, and the 1:25,000 Hiep Hoa map sheet indicates that its base is about $2.5 \mathrm{~m}$ above the present river bank. The mound was $160 \mathrm{~m}$ in maximum west to east dimension and $90 \mathrm{~m}$ across when surveyed in 1997, thus covering an area of about 1.5 ha. Today, the cutting away of most of the outer fringes of the former mound has reduced the now-levelled summit to about 90 by $65 \mathrm{~m}$.

An Son was initially excavated on a large scale in 1978, both on top of the mound and below it to the northeast. The mound-top trench was dug to a depth of $4.5 \mathrm{~m}$, and one of the northeastern trenches beyond the mound yielded an adult and two juvenile extended burials. The 1997 excavation by Nishimura and Nguyen (2002) was located on top of the mound at its eastern end. Like the mound-top trench in 1978, the 1997 trench was excavated to archaeologically sterile soil at a depth of $4 \mathrm{~m}$, revealing a series of horizontal layers that were divided into three main stratigraphic units by the excavators (see published section in Nishimura and Nguyen 2002: Fig. 3). The basal Unit 3, varying from 10 to $80 \mathrm{~cm}$ thick, incorporated the alluvial palaeosol that forms the stratigraphic foundation of the site and predated the visible importation of alluvial floor layers. Unit 2 above, between 2 and $3 \mathrm{~m}$ thick, contained a large number of alternating floors of quarried alluvial silt separated by occupation layers. The floors appear to have supported houses with posts set in holes up to $50 \mathrm{~cm}$ deep, although no specific plans could be reconstructed and it is unclear whether or not they had raised floors. Unit 1 above contained disturbed and historical period materials. Because the original section published as Nishimura and Nguyen 2002, Fig. 3, is no longer available for reproduction we show here instead (Fig. 3) a very similar section from the neighboring mound of Loc Giang (Fig. 1), drawn by Philip Piper and Armand Mijares in 2010. Loc Giang has similar layer characteristics to An Son.

By the time our excavation began in 2009, the mound top had been leveled and planted with trees, and the temple had been rebuilt on a much larger scale with many additional outbuildings. The west end of the mound had been terraced back from the road to create a steep slope $5 \mathrm{~m}$ high to make way for parking and a teahouse. The southern side of the mound was terraced into a vertical cliff to make space for a yard and houses. The eastern end had been stripped of soil to an unknown thickness, in part to construct some of the earthen house foundations that lift nearby modern houses above the Vam Co Dong monsoon season flood level, and in part to create some now abandoned rice fields to the east of the mound. In 2004 this area was chosen for the major excavation, which produced most of the An Son extended burials (Pham et al. 2006). A further trench that produced 2 juvenile skeletons and the burial of an adult female was dug at the base of the mound in 2007 (Van et al. 2008).

In 2009, three long trenches were laid out close to the 2004 trench series with the major intention of locating and excavating more burials. Trench 1 was 3 by $12 \mathrm{~m}$, 


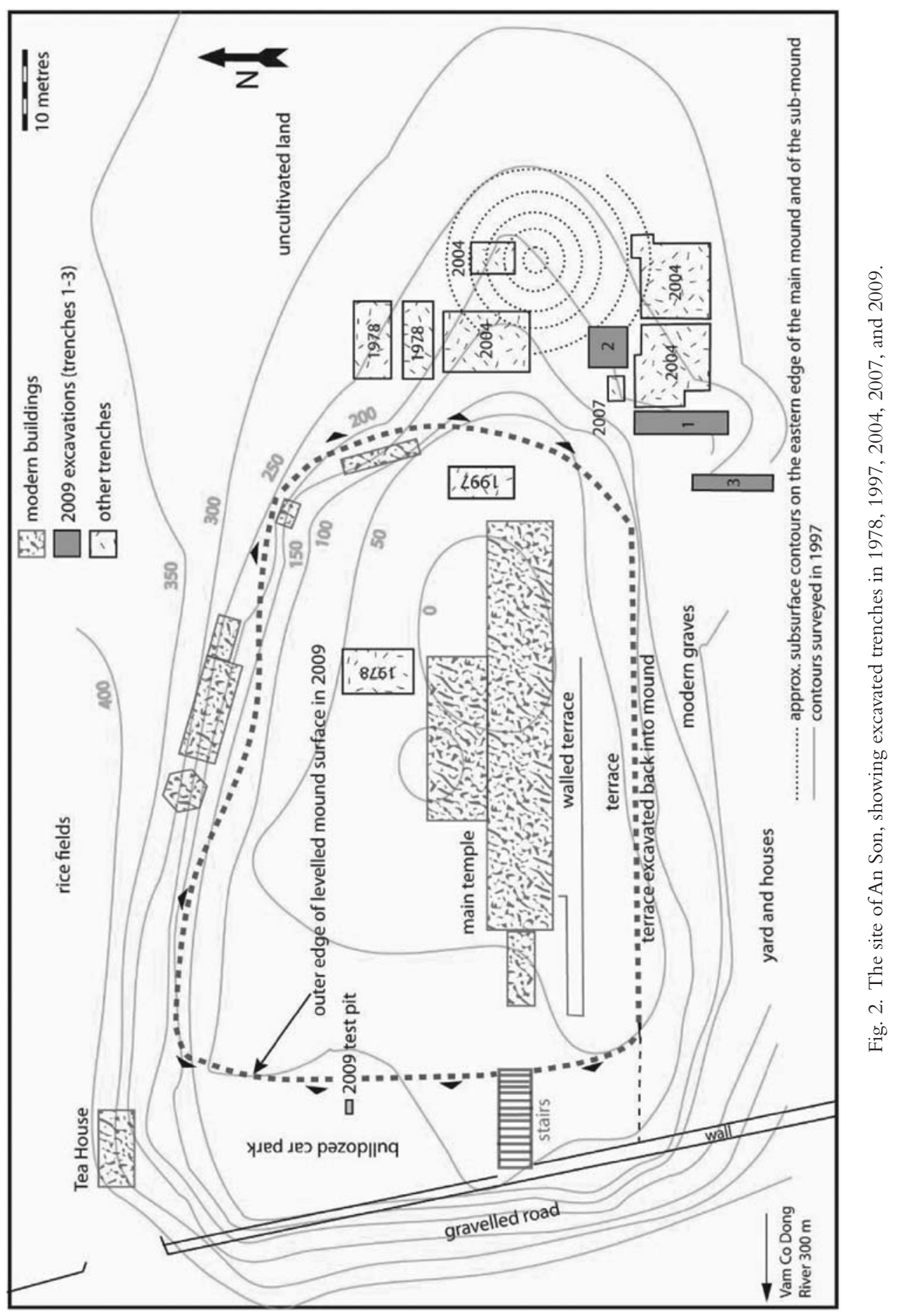




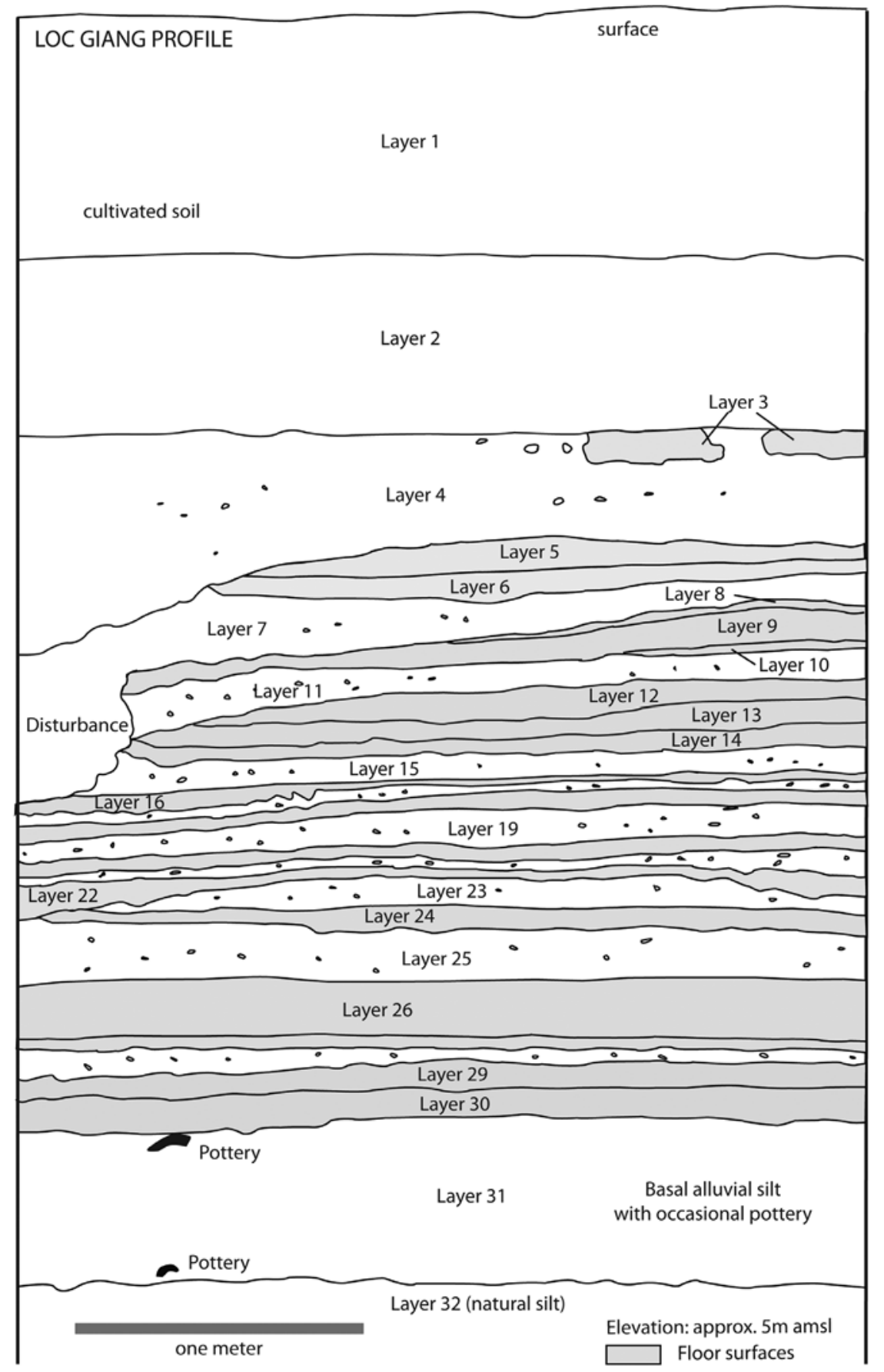

Fig. 3. A four-meter high section from the neighboring mound of Loc Giang (see Fig. 1 for location), drawn by Philip Piper and Armand Mijares in 2010. Loc Giang has similar layer characteristics to An Son. 
Trench 2 was 5 by $5 \mathrm{~m}$, and Trench 3 was 2 by $10 \mathrm{~m}$ in size. A 2 by $1 \mathrm{~m}$ test pit was dug at the western end of the site to intersect the basal levels that still survived beneath the recent terracing (see Fig. 2 for locations).

\section{AN SON STRATIGRAPHY AND THE CONSTRUCTION OF THE SITE}

The 1997 Pit 1, dug to a depth of $4 \mathrm{~m}$ from the top of the mound at its eastern end, indicates that most of the stratigraphy within the main mound was built up horizontally as a result of the constant renewal of occupation floors by layers of imported alluvial soil (see Fig. 3 for Loc Giang) presumably mined close to the site. Around the edge of the main mound, the picture is very different. Trench 1 dug in 2009 revealed clearly the outward dumping of sloping layers of occupation material, often containing large quantities of pottery sherdage, succeeding one another in what was probably a concentric fashion around the edge of the mound. Some of these layers slope downward and away from the mound at angles of 30 degrees or more.

The upper layers in the area of 2009 Trench 2 had all been stripped away before the 2004 and 2009 excavations commenced, but the excavated layers also sloped one over the other at angles of about 30 degrees, in this case toward rather than away from the main mound. Photos of the adjacent 2004 excavation also show clearly these sloping layers, which belonged to a subsidiary mound that incorporated both the 2004 and 2009 Trench 2 excavation areas, located to the east of the main mound. This is quite an important observation because it shows that large mounds such as An Son did not always accumulate continuously around only one center in a completely uniform fashion, as noted also by Higham and Higham (2009:138) for the culturally related mound of Ban Non Wat, located in the Mun River basin, a tributary of the Mekong, in northeastern Thailand.

Trench 2 of 2009 contained no certain postholes, so presumably this area was not used for house construction. The layers in Trench 2 give the impression of being successive rake-out deposits emanating from the eastern subsidiary mound, and those in the western half of the trench contained high densities of large potsherds, including many easily identifiable rims and lugs of the pottery stoves (ca rang in Vietnamese; see Fig. $5 d$ below) that are very characteristic of Vam Co Dong Neolithic assemblages. They also contained many freshwater gastropod shells, fish bones, and baked clay lumps, the latter of uncertain function but perhaps placed in cooking fires to retain heat, similar to the use of large stones in other regions of Southeast Asia and Oceania (stones do not occur naturally in the environs of An Son). Many soil concretions were also found in the eastern part of the trench, thought to indicate intensive cooking and perhaps the soaking into the ground of large amounts of animal fat.

Trench 3 contained mainly a dense and internally unstratified deposit consisting of clay and many small potsherds, the clay transported in suspension off the main mound by rainfall. A similar mass of transported clay and small potsherds also occurred in the southern end of Trench 1.

\section{THE DATING OF THE AN SON OCCUPATION}

Thirty-three radiocarbon dates are available for An Son, although two marine shell samples from 1978 are from unknown contexts and are not included in Table 1, a summary of the radiocarbon dates. The remaining 31 dates include a series of 13 (all 


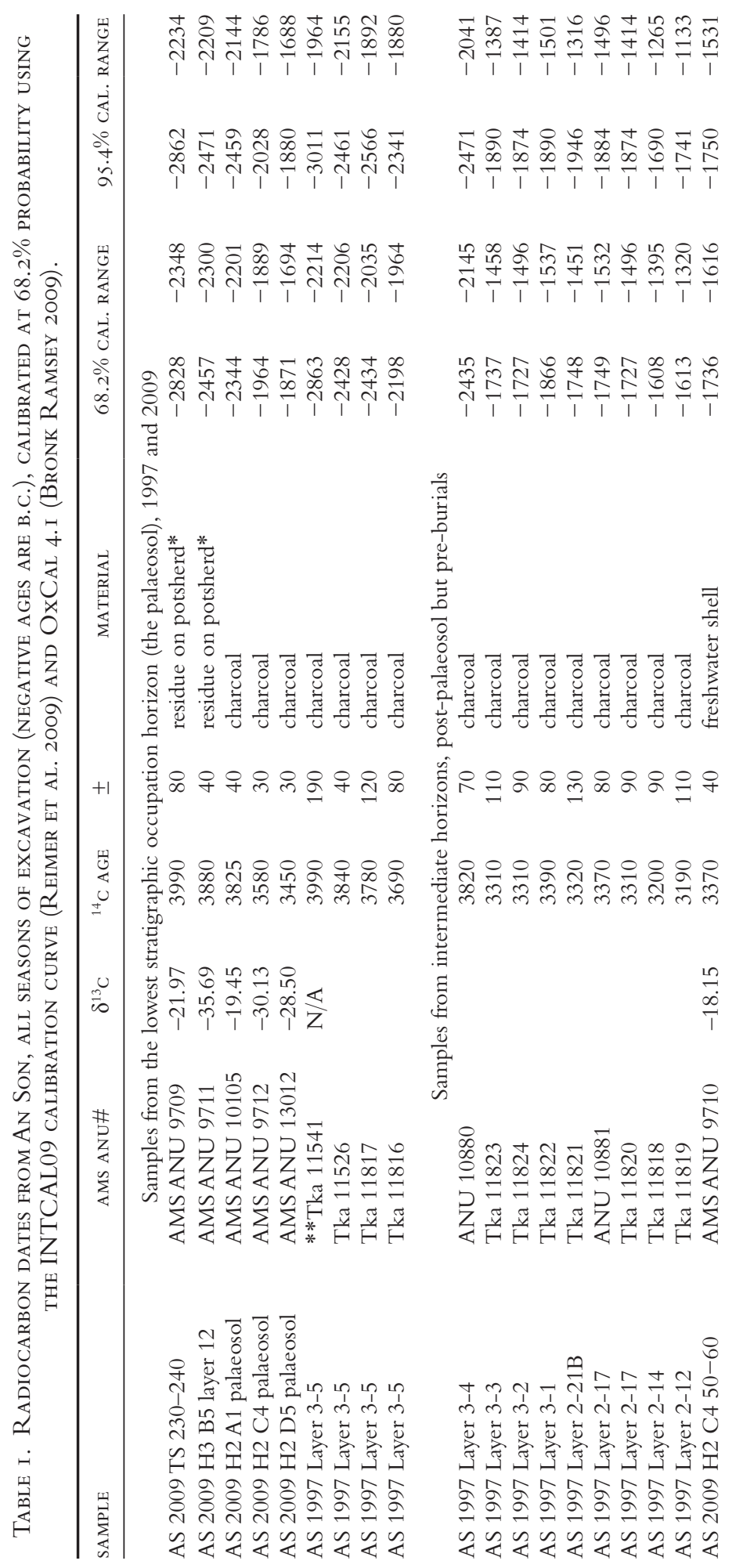




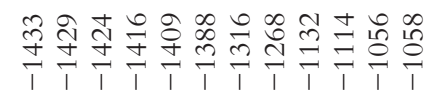

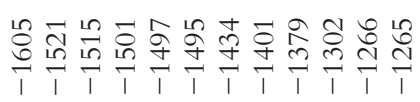

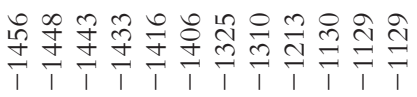

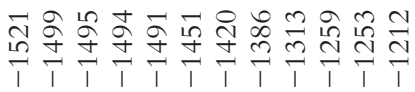

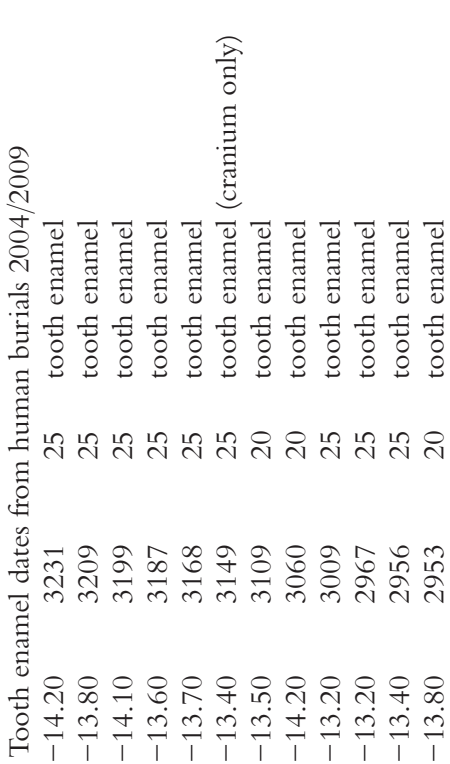

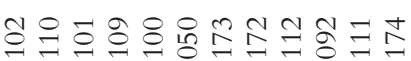

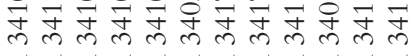

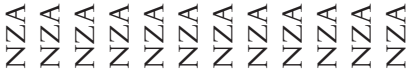

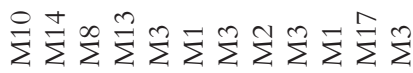

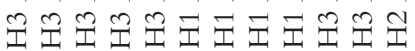

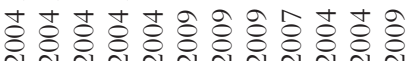

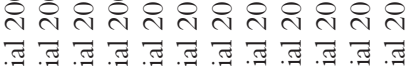

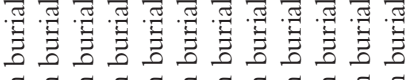

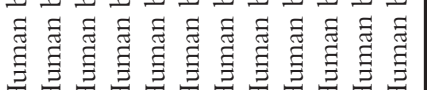




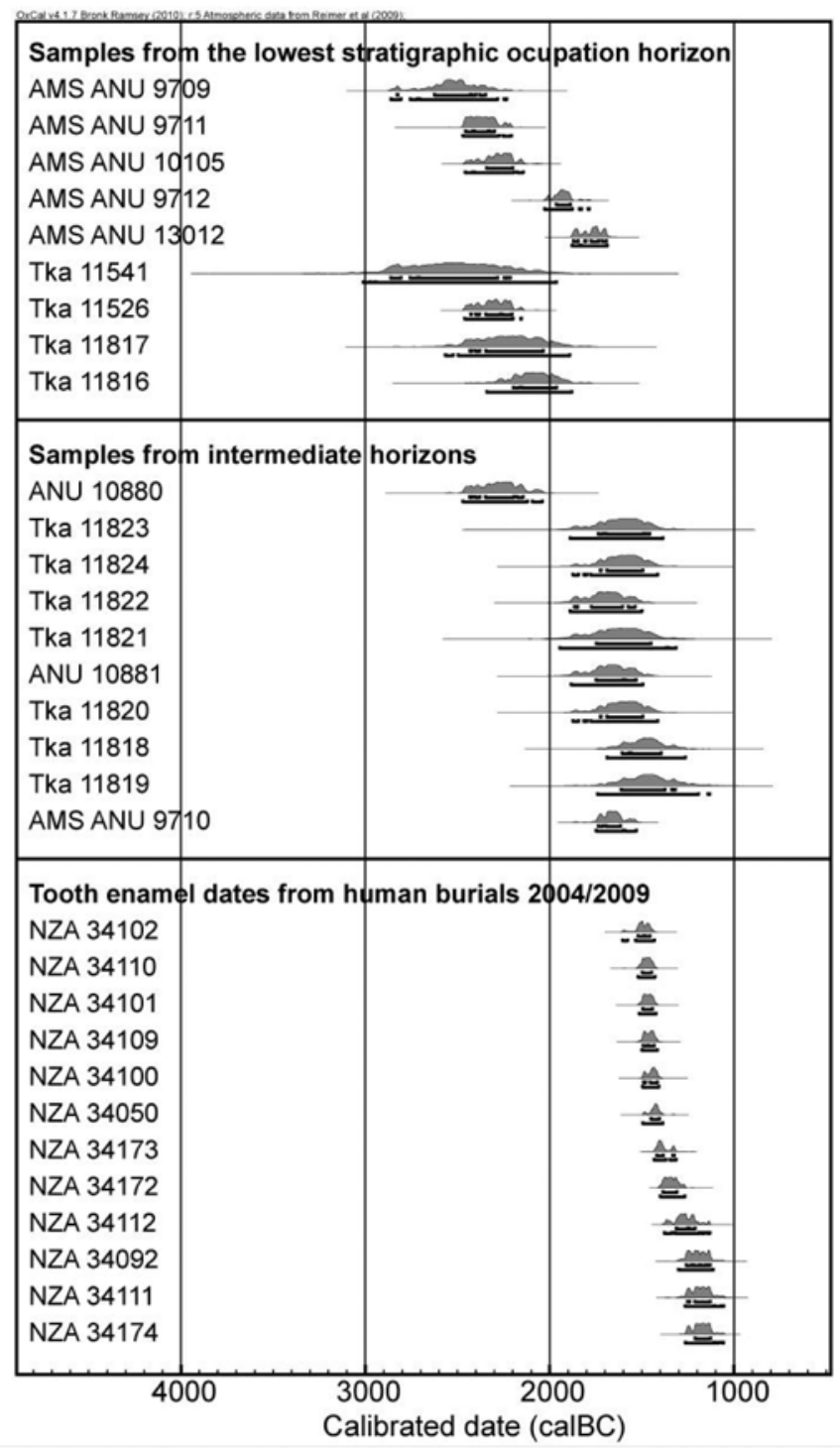

Fig. 4. The radiocarbon dates from An Son, 1997 and 2009 excavations. Calibrated at 68.2\% probability using the INTCAL09 calibration curve (Reimer et al. 2009) and OxCal 4.1 (Bronk Ramsey 2009).

charcoal) from the 1997 stratified main mound sequence; another 12 (all human tooth enamel) from the 2004, 2007, and 2009 adult burials; 3 charcoal and 2 food residue dates from the basal layers reached in 2009; and a single freshwater shell date from mid-sequence in 2009 Trench 2. All are incorporated into the plot shown in Fig. 4. They reveal a very coherent sequence of 21 samples, both charcoal and tooth enamel, that date from about 1800 to 1200 B.C., preceded by a series of determinations from six charcoal and two food residue samples that predate 2100 B.C. Samples ANU 9712 and 13012, both of charcoal from the base of 2009 Trench 2, are intermediate in date. 
Figure 4 suggests that An Son was occupied continuously from about 2300 to 1200 B.C., with no stratigraphic break or hiatus visible anywhere in the excavations. The cultural sequence, in terms of pottery rim form and decoration, also shows no interruption. The dates are slightly bunched toward the beginning and end of the sequence because this is where most of the samples were collected-basal layers at one extreme versus the later burial sequence at the other. Admittedly, the tooth enamel dates, without exception, are younger than the charcoal dates, but the burials excavated in 2004, 2007, and 2009 are all younger than the excavated layers in those trenches, because the upper layers from which they were cut had been removed before excavation began. So the correlation of date with stratigraphic order is very convincing. So too are the dates for the charcoal and food residue samples, because all the oldest ones come from the basal layers in the site. None stand out as strikingly inverted or out of place. Although one might wish to argue that some of the charcoal dates are too old (the old wood factor), and conversely that some of the tooth enamel dates are too young, there is really nothing in the site stratigraphy that could support such conclusions for all of the dates.

Determinations from tooth enamel have been shown to be problematic (e.g., Hedges et al. 1995), therefore some comments on the validity of the method need to be presented. The view of Zazzo and Sali'ege (2010), who recently reviewed the dating of bioapatite, is that tooth enamel is more resistant than bone to diagenetic alteration. It has proven reliable for extraction of stable isotope signals from archaeological samples because enamel is characterized by a closed and sequestered mineral structure, and is thus resistant to diagenetic effects (Lee-Thorp 2000; LeeThorp and Sponheimer 2003; Sponheimer and Lee-Thorp 1999). The $\delta^{13} \mathrm{C}$ of biogenic apatite with very low porosity, such as tooth enamel, can survive most diagenesis and retain a primary isotopic signature (Wang and Cerling 1994), although the degree of alteration varies significantly within and between sites (Lee-Thorp and Sponheimer 2003). Enamel has thus been routinely used for stable isotope paleodietary studies for over fifteen years.

The native radiocarbon isotope signal may allow for accurate dating, but no systematic study has been reported since Hedges et al. (1995). Zazzo and Sali'ege (2010), however, have recently presented a compilation of published dates obtained on enamel $(n=14)$ indicating that, while it is not exempt from isotopic exchange in temperate/wet environments, it might provide accurate ${ }^{14} \mathrm{C}$ ages for the Holocene, particularly in arid locations (Zazzo and Sali'ege 2010: fig. 5A, appendixes 337 and 343). The dating of bone collagen and tooth enamel from the same individual provides further evidence for the reliability of enamel dating from some contexts. Woodman and Beavan-Athfield (2009) have reported on the close agreement between radiocarbon determinations on paired samples of enamel and bone collagen from a Post-Clovis $\left(<10,530{ }^{14} \mathrm{C}\right.$ yr B.P.) mastodon in North America. Similarly, preliminary results from paired bone collagen and tooth enamel from Iron Age sites in Cambodia have also produced congruent results. While acknowledging that further scientific work is required, these results suggest that tooth enamel has some potential for age determination on archaeological teeth.

Two of the early dates from An Son, ANU 9709 and 9711, are on burnt food residues inside potsherds. These have very negative $\delta^{13} \mathrm{C}$ values that imply terrestrial rather than marine food sources, hence obviating any need for a marine reservoir correction. There is also no known limestone in the catchment of the Vam Co Dong. 
Sample ANU 9709 comes from the base of the 2 by $1 \mathrm{~m}$ test excavation, and ANU 9711 from a sherd cluster at the base of Trench 3 . The calibrated age ranges span 2800-2200 B.C. The carbon contents of both samples were sufficiently high to allow some confidence in the reliability of the measurements (S. Fallon, ANU AMS Laboratory, pers. comm.).

The samples ANU 9712 and 13012 are both slightly younger than the basal series, with a calibrated range of $2000-1700$ B.C. It is suggested that this time span may represent the beginning of occupation in the area of 2009 Trench 2 and the 2004 excavation. The youngest date from an occupation layer in 2009 Trench 2, on a freshwater shell from layer 4 in square C4 (ANU 9710), has a calibrated range from 17501531 в.C. The whole set thus suggests dates in the first half of the second millennium B.C. for the deposition of the Trench 2 rake-out layers, just prior to the beginning of the burial phase.

Obviously, there are uncertainties associated with the dating of potentially old wood, tooth enamel, and unidentified food residues in pottery, magnified by the fact that the site has been excavated on separate occasions, with stratigraphic sequences that are difficult to merge into a common site history. In an ideal scenario we would apply Bayesian methods to the modeling of the calibrated ages, but in this instance there are so many uncertainties, both in the stratigraphic constraints that could be applied within such a model and in the sample issues with the dated series, that this could only be undertaken in the broadest and most general terms. Under these conditions it is possible that modeling would produce results that are importantly wrong. Instead, we conclude provisionally that initial occupation on the site occurred before 2000 B.С., and possibly as early as 2400 B.C. A simple Bayesian model, including a charcoal-specific outlier detection approach (after Bronk Ramsey 2009), of samples from the earliest stratigraphic horizons (as shown in Table 1) suggests that occupation started between 2530 and 2205 B.C. (68.2\% range). Modeling also shows that the phase of activity represented by determinations dating to the intermediate horizons finished between 1540 and 1480 B.C. (again at 68.2\% prob.). The placing of the burials, if all of the dates are assumed to be reliable, occurs between approximately this date and much later, at $\sim 1250-1050$ в.C. The termination of usage of the site could, therefore, have been as late as 1050 B.C., in which case the total absence of copper or bronze is interesting in light of recent debates on the chronology of metallurgy in Southeast Asia. No early historical material (post-A.D. 1) was found during our 2009 excavations, probably because of the removal of the upper layers beforehand.

\section{THE AN SON POTTERY}

The pottery sequence described in 1997 was divided into four cultural periods, from 1 at the base to 4 at the top (Nishimura 2002; Nishimura and Nguyen 2002). The excavators noted that the very base of the site underneath the main mound, layer 3-5 (cultural period 1), lacked the fiber tempers and wavy-rimmed forms that characterize the layers immediately above. We confirmed this by examining the materials stored from the 1997 excavation in the Long An Museum, and while the sample size is very small there can be no doubt that the 1997 layer 3-5 pottery also has more punctate decoration and calcareous sand temper than occur in the later layers. We did not hit very clear traces of this layer in 2009, although we did find materials of this phase 
mixed into the basal palaeosols in Trenches 1 and 3. Only a large future excavation in the center of the main mound is likely to clarify the full content of 1997 layer 3-5. Otherwise, the pottery excavated in 2004 and 2009 essentially replicated that from 1997 periods 2 to 4 . The main additions from the more recent excavation seasons have been the complete pots found as grave goods (Fig. 5).

The major aim of the 2009 An Son ceramic analysis, undertaken by Carmen Sarjeant for her completed PhD thesis at ANU (Sarjeant 2012a, 2012b), has been to characterize the sequence thoroughly for variations in vessel and rim shape, fabric and decoration. She is currently preparing the details for publication and here we focus only on describing the complete vessels found with the burials (1500 to 1200 B.C.), together with the punctate and incised sherds from the lowest layers in the site.

The complete vessel forms identified with the An Son burials in 2004 and 2009 are independent-restricted or unrestricted in the terminology of Anna Shepard (1964; see also O'Reilly $2004: 233-236)$. Figure $5 f, g, i, j$, and $k$ are examples of independentrestricted vessels with everted rims, often with ring feet. Figure $5 f$ and $i$ have internally hollowed rims and are an especially common form, sometimes being finely decorated with horizontal incised and rouletted bands around their upper bodies. Figure $5 a$ (with Fig. 6), $e$, and $h$ are examples of unrestricted bowls with direct rims, often on high pedestals. Figure $5 a$ /Figure 6 is an absolute masterpiece within this group, discarded broken rather than found as a grave good. Figure $5 b$ and $c$ represent the special classes of wavy- and serrated-rimmed vessels, and Figure $5 d$ is a reconstruction of a typical ca rang pottery stove (no ca rang were found complete).

The wavy- and serrated-rimmed bowls are especially common in the burials, with the former apparently predating the latter. A significant presence of the wavy-rimmed form occurred to the base of the deposits excavated in 2009, especially in the test pit and Trenches 1 and 2. However, this form was absent at the very base of the main mound in 1997 (layer 3-5; Nishimura and Nguyen 2002:104), and made its first appearance during the 1997 cultural period 2 .

The recorded decoration types and/or surface treatments on the An Son burial pottery include coarse cord marking and multiple-toothed combing over the lower parts of pots, together with burnishing, incision, red slipping, roulette stamping, moulding/ appliqué, and white lime or clay infill in the decorated areas (Figs. 6 and 7). Cord marking and combing occur throughout the sequence, but there is no carved paddle decoration.

The basal pottery assemblage in the site is particularly interesting. Punctate decoration within incised lines is common in 1997 layer 3/5 and the lower layers in 2009 Trenches 1 and 3. The motifs present at An Son (Fig. 8) resemble those from Nong Nor Phase 1 (O’Reilly 1998: fig. 42) and Khok Phanom Di Ceramic Period 1 (Vincent 2004: chap. VII) in central Thailand, dated together between c. 2400 and 1800 B.C. Khok Phanom Di Ceramic Period 1 also has hole-mouthed and restricted cordmarked rims (Vincent 2004: fig. 41, top left), a form common in the lower layers at An Son. Unfortunately, the absence of complete pots from the lower layers in Nong Nor and An Son makes full shape comparisons very difficult. Nevertheless, the similarities are striking, particularly because all three sites went on to develop pottery styles in their middle and upper layers that were much more localized in distribution. For instance, punctate stamping receded in importance in the middle and upper layers at An Son, and a form of rouletting became more common, perhaps made with a 


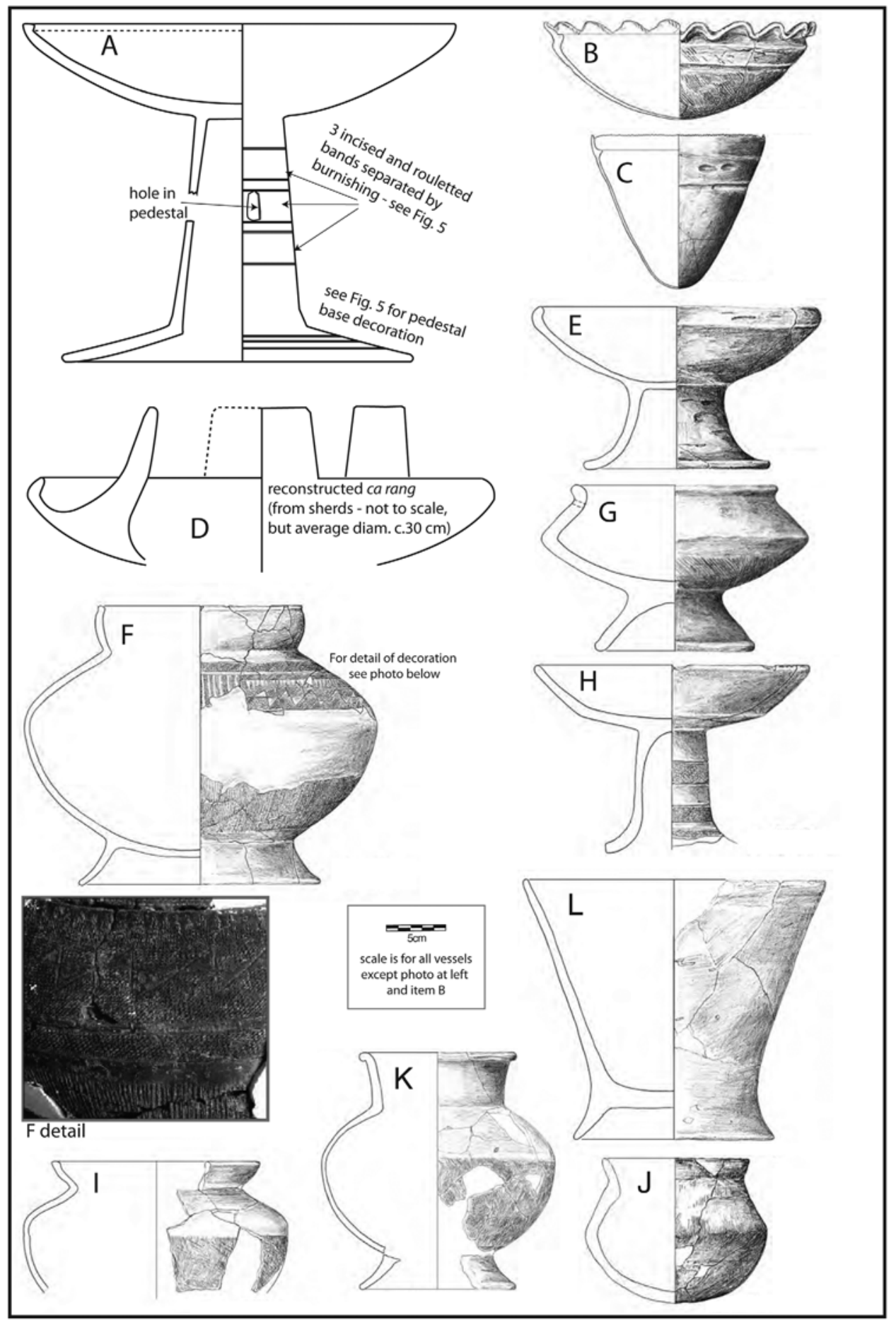




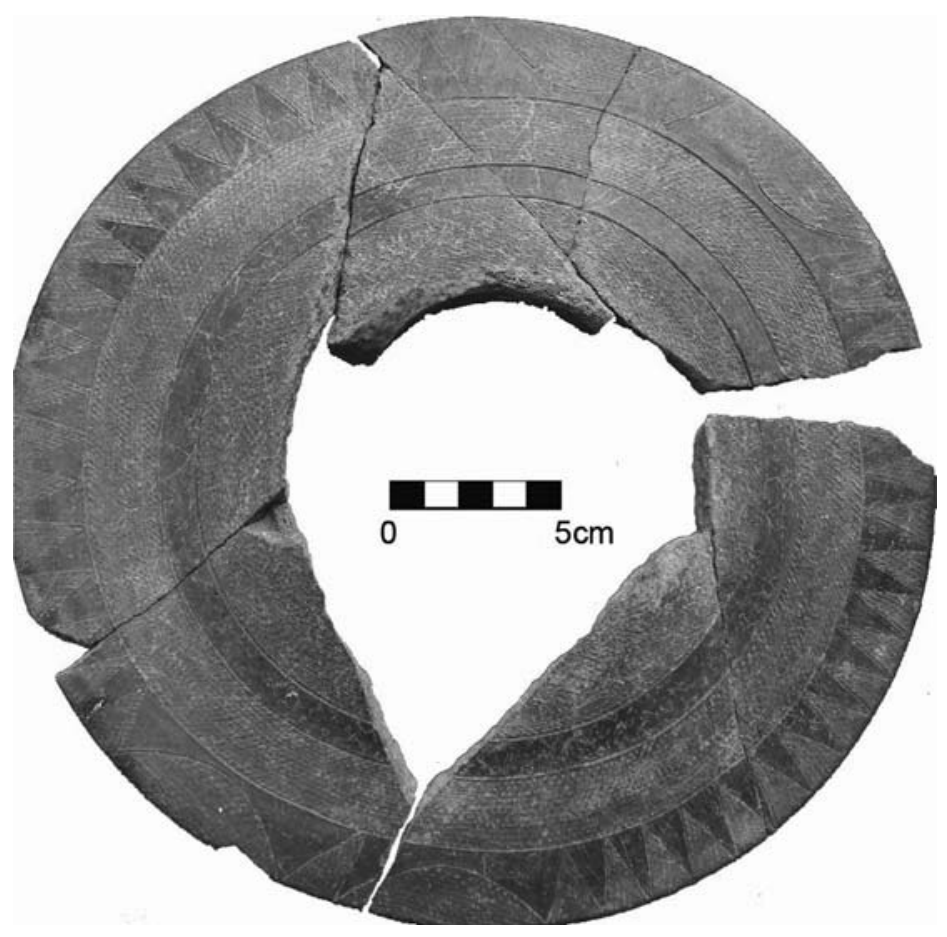

Fig. 6. The decorated pedestal of the vessel shown as Fig. 5a, with alternating zones of fine punctate stamping or rouletting, and burnishing. The outer triangular motifs also occur on pedestal bases from the nearby site of Loc Giang.

Fig. 5. Pottery from An Son 2009 dating between c. 1600 and 1200 B.c., drawn by Nguyen Quoc Manh (except for $a$ and $b$ ).

a. Grit-tempered pedestalled dish with alternating bands and triangular motifs outlined with incision, and filled with either burnishing or rows of fine rouletting, the latter made by a multiple-toothed implement that appears to have been rolled over the surface. From an occupation context in Trench 1 . The decoration on the pedestal base is shown separately in Fig. 6.

b. Grit-tempered wavy-rimmed open bowl, placed as item 4 with Trench 1 burial 3 (Fig. 8: 1431-1314 BC, NZA 34173).

c. Grit-tempered serrated-rimmed open bowl, from a discard zone in Trench 1.

d. A ca rang pottery cooking stove reconstructed from sherds, these being fiber-tempered open bowls with three internal and upwards-projecting lugs to support cooking pots (not drawn to scale).

$e$. Undecorated fiber-tempered pedestalled dish with rice impressions, from discard zone in Trench 1.

$f$. Footed grit-tempered and burnished vessel with extemely intricate bands and triangles outlined by incision and filled with parallel rows of fine punctation, made by a multiple-toothed implement (photo includes detail reproduced at 3.5 times the scale of item F). The lower part of the pot is cord-marked. Placed as item 2 with Trench 1 burial 2 (Fig. 7: 1397-1267 BC, NZA 34172).

g. Undecorated sand-tempered pedestalled dish placed as item 1 with Trench 2 burial 3 (Fig. 7: 12621057 BC, NZA 34174).

h. Fiber-tempered pedestalled dish with rouletted bands around pedestal, like those on vessel A (above), from a discard zone in Trench 1.

i. Upper part of a vessel similar to vessel $\mathrm{F}$ (above) but without the punctate stamping, from a discard context in Trench 1 . The lower body is finely comb-incised.

$j$. Undecorated fiber-tempered vessel placed as item 4 with Trench 1 burial 2 (Fig. 7: 1397-1267 BC, NZA 34172).

$k$. Sand-tempered footed vessel with cord-marked lower body and a high neck, from an occupation context in Trench 1.

l. Fiber-tempered footed beaker, undecorated. Placed as item 1 with Trench 1 burial 2 (Fig. 7: 13971267 BC, NZA 34172). 

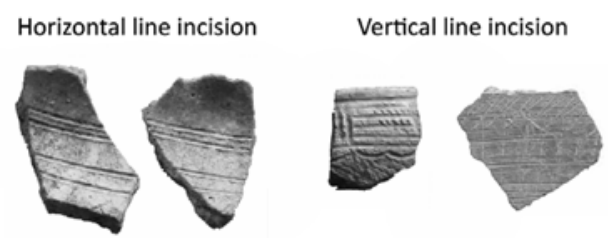

Triangle incision

Criss-cross incision
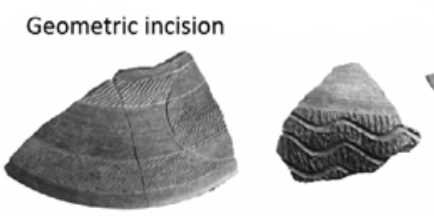

Wavy incision
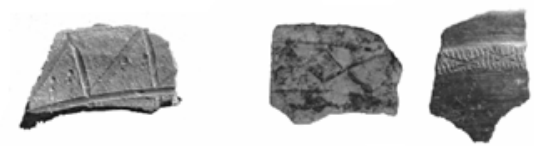

Concentric circle incision

Red paint

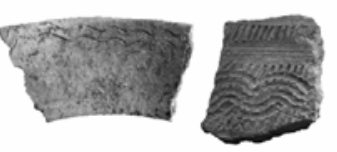

Zigzag incision

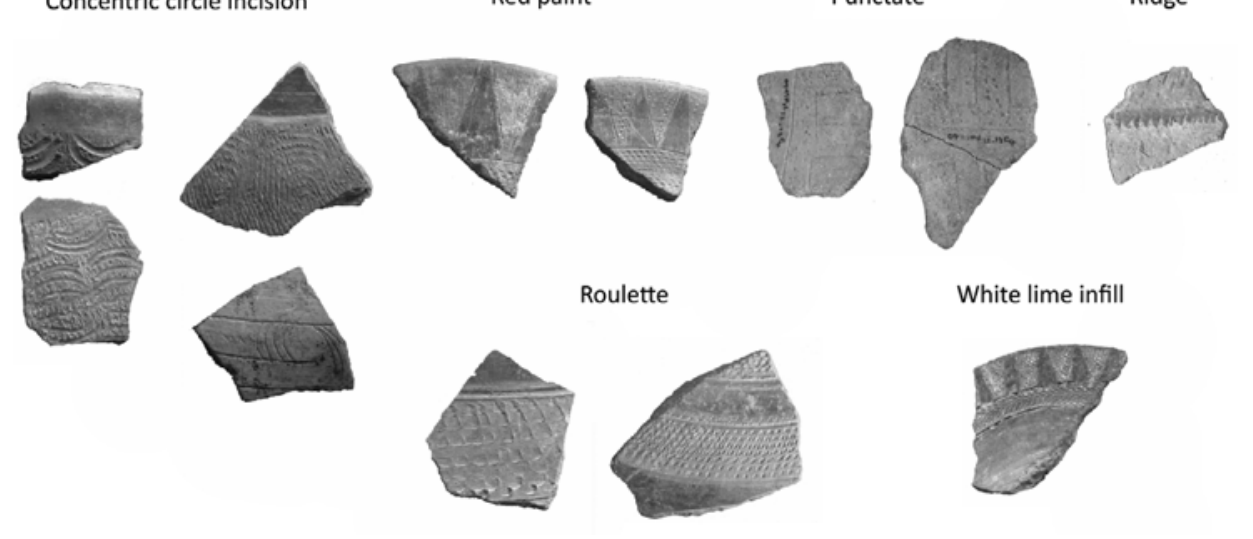

Fig. 7. Examples of incised, stamped, painted and appliqué body decoration from the 2009 excavations at An Son, c. $1800-1200$ B.C. (prepared by Carmen Sarjeant).

rolled or rocked implement (see Fig. 7). This form of rouletting appears to be less developed or absent in contemporary Thailand Neolithic sites such as Ban Non Wat (Higham and Kijngam 2009, 2010).

The An Son pottery fabrics, primarily fiber or sand, have been analyzed by scanning electron microscopy with an energy dispersive spectrometer attachment (SEM-EDS). Both mineralogical and chemical compositional analyses were conducted. Fibertempered fabrics contain plant remains that in most cases can be identified as rice chaff (see Tomber et al. 2011 for comparable images), and these are present from the base of the deposits excavated in 2009 but were not present in the very basal layer 3-5 excavated in 1997. Fiber tempers were sometimes associated with calcium phosphate (apatite) and iron phosphate (vivianite), which may be the result of phosphatic mineralization of the plant fibers (Green 1979) in the temper, or the addition of crushed bone as well as fiber to the clay fabric (Kuczumow et al. 2010; Piga et al. 2009).

The sands include feldspars (predominantly orthoclase) and quartz. Sometimes, these sand-tempered vessels also incorporate lateritic materials, usually micas and amphiboles, which most likely weathered naturally into the clay sources. A few rare examples of shell temper include grains with jagged edges and a composition of cal- 

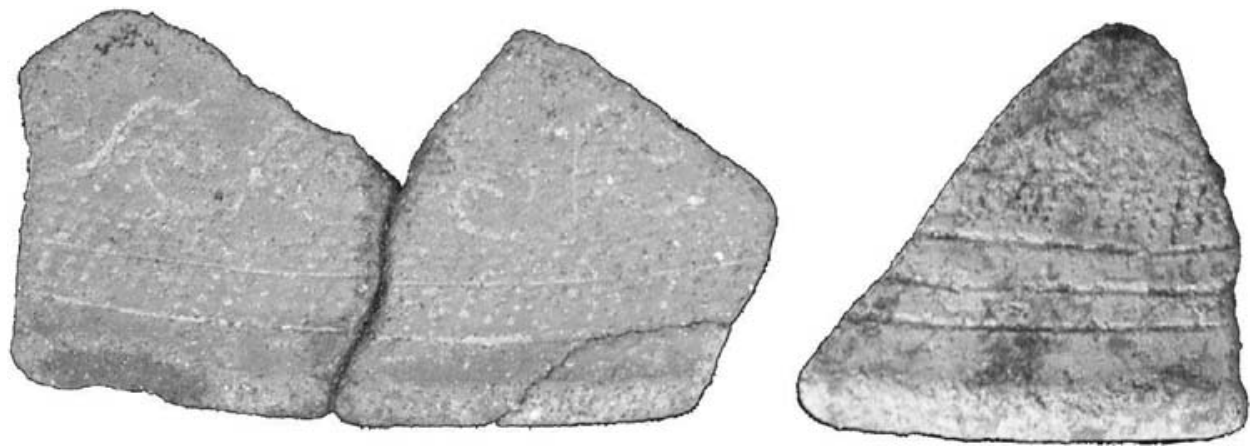

Fig. 8. Examples of incised and punctate stamped decoration from the base of An Son, before 2000 B.C. Left: 1997 layer 3-5. Right: An Son 2009 Trench 3, basal layer.

cium carbonate. The shell-tempered fabrics sometimes also include fibers, quartz, and amphibole. The clay matrices frequently include zircon and ilmenite (iron and titanium oxides), regardless of the selected temper.

In terms of regional comparisons, Nishimura (2002; Nishimura and Vuong 1997) has compared the pottery from the An Son 1997 excavations to that from other Vam Co Dong and Dong Nai Neolithic sites. The nearby site of Loc Giang has the same material assemblage as An Son, specifically with pedestal vessels similar to Figures $5 a$ and 6, wavy-rimmed bowls, and ca rang stove sherds (Quang and Ngo 1994). The $\mathrm{Cu}$ Lao Rua ceramic assemblage from the Dong Nai valley to the east also shares some features with An Son, including incised wave, linear, triangular, and circular incision, punctate stamping, and waves incised over paddle-impressed or combed lines (Sarjeant, personal observations in Binh Duong Provincial Museum). This site also has sand, fiber, and shell tempers, like An Son. A number of the rim forms at $\mathrm{Cu}$ Lao Rua are paralleled at An Son, including concave everted rims (cf. Fig. $5 f$ and $i$ ), carinated bowls, and ca rang with rounded projections. The nearby site of Binh Da contains several of the An Son rim forms and ca rang with square projections, but like Cu Lao Rua it lacks the wavy-rimmed bowls. Binh Da also shares with An Son the incised wave motif over paddle or comb impressions. Nishimura (2002) suggests that Binh Da and An Son have contemporaneous sequences, although An Son commenced earlier.

Da Kai (Nishimura et al. 2009), located $150 \mathrm{~km}$ to the east of An Son in the upper reaches of the Dong Nai River in Binh Thuan Province, also shares many An Son rim forms. Decoration includes incised zones filled with punctate or incised fills, as at An Son, and again it is likely that the two sites were contemporary (Nishimura 2002; Nishimura et al. 2009).

These sites in southern Vietnam indicate that there was a common Neolithic ceramic tradition throughout the region with common rim forms and decoration. Perhaps the most distinctive marker for the region, together with the ca rang form of pottery stove, is the everted rim restricted vessel with shoulder bands of punctate and roulette stamping between horizontal incised lines (Fig. $5 f$ ), although this was not present in the oldest occupation phase. On the other hand, it can be expected that each site will also possess unique ceramic forms, perhaps for purposes connected with identity, and in the case of An Son and neighboring Loc Giang the wavy-rimmed ceramics appear to be have been such a unique component. 
Beyond southern Vietnam, many sites in northern Vietnam and central and northeast Thailand contain Neolithic assemblages contemporary with An Son. The parallels with the early sites of Nong Nor and Khok Phanom Di have already been noted, but cultural sharings continued onward well in to the second millennium B.C. The Neolithic ceramic assemblage at Tha Kae, in central Thailand (Rispoli 1992, 1997, 2007), includes a zigzag incised pattern, not generally common in central Thailand, which resembles the band motifs on some vessel shoulders at An Son (Rispoli 2007). The Tha Kae ceramics were tempered with either quartz sand or coarse vegetal particles, much like those at An Son. In northeast Thailand, the Neolithic layers of Ban Non Wat, dating from 1800 B.C. onward (Higham and Higham 2009, 2010), also contain everted concave rimmed restricted vessels like those at An Son (cf. Fig. $5 f, i$ ). The panels at An Son with punctate and roulette stamped fill, in association with burnishing, are paralleled especially in this site (Sarjeant 2012; Higham and Kijngam 2009; and compare Fig. 6 here with Higham and Wiriyaromp 2010, Fig. 5.8).

Indeed, the presence of an "incised and impressed" tradition among ceramics from Neolithic contexts in Southeast Asia (Rispoli 2007), going back into the late third millennium B.C., undoubtedly extended into southern Vietnam. Sites in central and northeast Thailand appear to have the closest shared ceramic affiliations with those in southernVietnam, and there is apparently less held in common between northern and southern Vietnam Neolithic assemblages. For instance, the pottery from the Phung Nguyen-related site of Man Bac, in Ninh Binh Province in northern Vietnam, is dominated by carved paddle impression rather than cord marking and combing, and shares few specific forms and decorative techniques with An Son (see illustrations in Nguyen et al. 2011). This suggests the former existence of a "Greater Mekong" cultural network dating from about 2500 B.C. onward, with a foundation that involved migration and settlement by a Neolithic population that lacked any obvious Hoabinhian cultural antecedents.

\section{THE AN SON NON-POTTERY ASSEMBLAGE}

As in 1997, the stone tool assemblage excavated in 2009 included shouldered and unshouldered adzes and axes (Fig. $9 g$ ) and flakes with polished surfaces that were presumably derived from the rejuvenation of these tools. A flaked (unpolished) lithic technology was conspicuously absent, and no evidence was found for the initial stages of adze or axe manufacture. Of the 170 identifiable cross sections of adzes or axes excavated in 2009, either complete or fragments, all were quadrangular in cross section. There was a mixture of both shouldered and unshouldered adzes throughout, although the unshouldered ones were absent in the lowest spits in Trench 1, suggesting a sequence from shouldered to unshouldered similar to that reported for An Son in 1997, and from other nearby late Neolithic and Bronze Age sites such as Rach Nui (Bui et al. 1997).

A total of 70 small baked clay pellets (Fig. 9c) were identified in the 2009 excavation, none in burial contexts. These items are generally considered to have been used with the pellet bow for hunting small animals and birds. Interestingly, baked clay spindle whorls were absent, as in other Neolithic sites in southern mainland and island Southeast Asia. This may be due to the absence of a need for clothing (following suggestions by Gilligan 2010) in these hot and humid tropical latitudes. Conversely, spindle whorls are present in Neolithic sites in northern Vietnam, northern Philip- 


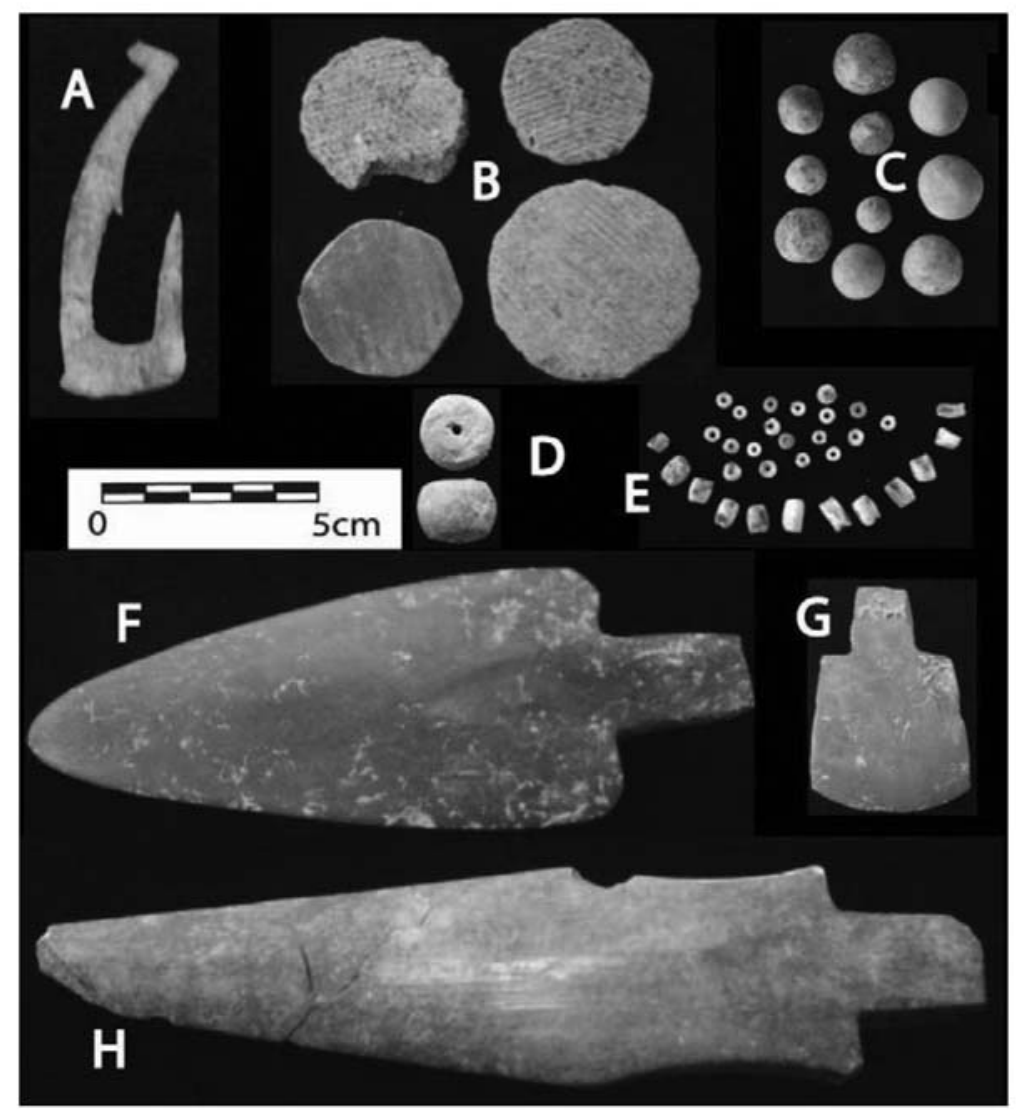

Fig. 9. Other artifacts from An Son, c. 1600-1200 B.c.

a. Barbed bait hook of turtle bone, $5.4 \mathrm{~cm}$ long and excavated in 2004 (Long An Museum accession no. 1740-177.2).

b. Potsherd discs (gaming pieces?).

c. Baked clay pellet bow pellets.

d. Shouldered stone adze.

e. Shell disc and cylinder beads.

$f$. Tanged stone point.

g. Bone or ivory "dagger", possibly of elephant tusk, $23.7 \mathrm{~cm}$ long and excavated in 2004 (Long An Museum accession no. 1739-XS.176).

pines, Taiwan and southern China (Cameron 2002), perhaps because of the increasing presence there of a fairly cold dry season.

Apart from 15 small shell beads found in burials in 2009, all remaining shell beads were recovered from 1.2 and $2 \mathrm{~mm}$ wet sieving. 129 were disc shaped, 63 were elongated rectangular or oval, and 4 were square (Fig. $9 e$ ). Most were very small, the discshaped ones between 2 and $4 \mathrm{~mm}$ in diameter and just $1 \mathrm{~mm}$ thick. One broken bone fishhook was found at the base of Trench 2, similar to several found in previous excavations at the site (Fig. 9a).

Like the pottery, the An Son non-ceramic material culture is also remarkably similar in many respects to that from contemporary Neolithic sites in central and northeastern Thailand, such as Nong Nor, Khok Phanom Di, and Ban Non Wat (Higham 
and Kijngam 2009, 2010). For instance, Ban Non Wat also contained small spherical pellets of baked clay used as missiles with a pellet bow, clay beads, small shell disc beads, and round potsherd "counters" similar to those from An Son, although An Son lacked the baked clay mushroom-shaped potting anvils present in Ban Non Wat. Potting anvils, however, do occur in other Neolithic sites such as Suoi Linh in the Dong Nai valley, as well as in Red River delta sites such as Man Bac in northern Vietnam.

\section{THE HUMAN BURIALS FROM AN SON 2009}

Six skeletons and a separate skull were recovered during the 2009 field season, bringing the total number of individuals (not all complete skeletons) from the site to 35 (including the 3 from 1978, 20 from 2004, and 5 from 2007). The analysis of the human remains will be presented by Anna Willis in her Ph.D. thesis, and here we list only the 2009 discoveries (Table 2). The human remains from the 1978, 2004, and 2007 excavations have been discussed briefly in earlier Vietnamese reports (Dang et al. 2008; Nguyen 2005; Pham et al. 2006).

A multifactorial approach was applied in the osteological analysis of the individuals using as many indicators as possible to estimate their age, sex, and health. Age estimates for subadults were based on dental formation, calcification stages and eruption, diaphyseal length, epiphyseal fusion, skeletal maturity, and size. Tooth formation, calcification, eruption, and length were assessed using appropriate standards (Liversidge et al. 1993; Ubelaker 1989). Long bone length was used to establish age estimates for neonates with limited formation of dentition, using linear regression equations based on fetuses of known gestational age, following Tocheri and Molto (2002). For adolescents and young adults, tooth eruption, epiphyseal fusion (Buikstra and Ubelaker 1994), and the length of the femur (Rissech et al. 2008) were assessed. The ages of older adults would normally be based on the pubic symphyses and auricular surfaces of the os coxae, but no individuals had pubic symphyses preserved and those that had auricular areas were not preserved very well. As a result, tooth wear was also scored using Scott's technique (Scott 1979), and the data were then used in regression equations developed by Oxenham (2000) on skeletal material from northern Vietnam. Sex estimation was not attempted for subadults. Sex was estimated for adults using the cranium and the os coxae where present (Buikstra and Ubelaker 1994; Phenice 1969; Walrath et al. 2004).

Table 2. Excavated burials at An Son, 2009

\begin{tabular}{|c|c|c|c|c|}
\hline & BURIAL & AGE & SEX & GRAVE GOODS \\
\hline Trench 1 burial 1 & Adult & $40-49$ years & $\mathrm{F}$ & $\begin{array}{l}\text { None certain (skull only). Possible potsherd } \\
\text { sheet below, and dog mandible }\end{array}$ \\
\hline Trench 1 burial 2 & Adult & $20-29$ years & $\mathrm{F}$ & Various-see text, Figs. $5 f, j$, and $l$ \\
\hline Trench 1 burial 3 & Adult & $30-39$ years & $\mathrm{M}$ & $\begin{array}{l}\text { Fig. 10: two wavy-rimmed bowls of vessel } \\
\text { class D }\end{array}$ \\
\hline Trench 1 burial 4 & Subadult & $1-4$ years & - & $\begin{array}{l}\text { Fig. 10: one serrated-rimmed bowl of vessel } \\
\text { class D }\end{array}$ \\
\hline Trench 2 burial 1 & Subadult & $<1$ year & - & None \\
\hline Trench 2 burial 2 & Subadult & $<1$ year & - & $\begin{array}{l}\text { One cord-marked globular vessel with everted } \\
\text { rim, two cylindrical shell beads }\end{array}$ \\
\hline Trench 2 burial 3 & Subadult & $10-14$ years & - & Various see text \\
\hline
\end{tabular}


Every individual was assessed for any pathological indicators. There was some evidence for nonspecific indicators of stress, and a high prevalence of caries. Some individuals had linear enamel hypoplasia, suggesting that they were stressed at some point during childhood when their permanent dentition was forming. However, many of these individuals survived this stress and lived into adulthood. There was little evidence for cribra orbitalia or porotic hyperostosis. There was little evidence for trauma and no individuals had broken limbs, suggesting low levels of interpersonal violence. Each burial is now given a brief description.

Trench 1, Burial 1, Dated by NZA 34050 to 1492-1387 B.C. Female, 40-49 Years This individual was only represented by the cranium, with no mandible or postcranial remains in association. It was lying on its right side facing west, complete and in very good condition with evidence of damage, suggesting that it might have been disturbed out of a burial. It appeared to be lying on an intentionally placed, isolated cluster of pottery fragments, a potsherd sheet, which also featured a dog mandible. These items may have been intentionally placed as grave goods.

Trench 1, Burial 2, Dated by NZA 34172 to 1397-1267 B.C. Female, 20-29 Years, Oriented Northeast/Southwest - This individual was incomplete and very poorly preserved, being represented only by the skull and the shafts of the left humerus, femora, tibiae, and right fibula (Fig. 10a). She was buried supine with nine pottery vessels, one between the tibiae (the footed beaker, item 1 in Fig. 10a), three along/under the right side of the lower limbs (items 2, 3, and 4 in Fig. 10a, and Figs. $5 f$ and $j$ for items 2 and 4), and five along/under the left side of the lower limbs (items 5, 6 [neither reconstructed], 7, 8, and 9 in Fig. 10a). There were also four non-pottery artifacts that may have been associated with this burial: an unshouldered adze beside the right tibia (item 10), a shouldered adze beside the left tibia (item 11), a shouldered adze beyond the area of the right foot in square B10 (item 12), and an unprovenanced burnishing stone.

Trench 1, Burial 3, Dated by NZA 34173 to 1431-1314 B.C. Male, 30-39 Years, Oriented Northeast/Southwest - This individual was almost complete, but the right side had been disturbed and removed during the later interment of child burial 4 . This supine individual had variable preservation; the facial region and maxilla of the skull were crushed and poorly preserved and the articular epiphyses of all of the long bones were degraded. Two wavy-rimmed open bowls were in association. One, over the proximal right tibia (item 1), had been cut in half during the placement of Trench 1 burial 4, and one (item 2) was over the distal tibiae and calcanii (Fig. 10b). Sherds of pottery were found under the skull, perhaps placed intentionally, and an unshouldered adze was found nearby.

Trench 1, Burial 4, Not AMS Dated. Child 1-4 Years, Oriented Northeast/Southwest This child was almost complete but had variable preservation, with articular epiphyses degraded and the hands and feet completely degraded. There was a serrated-rimmed open bowl placed to the right of the tibiae (item 1 in Fig. 10), and intentionally placed sherds of pottery under the skull. This burial cut through Trench 1 burial 3, indicating a later interment.

Trench 2, Burial 1, Not AMS Dated. Infant <1 Year, Oriented Southeast/Northwest - This neonate was complete and very well preserved. There were no grave goods associated with it. 

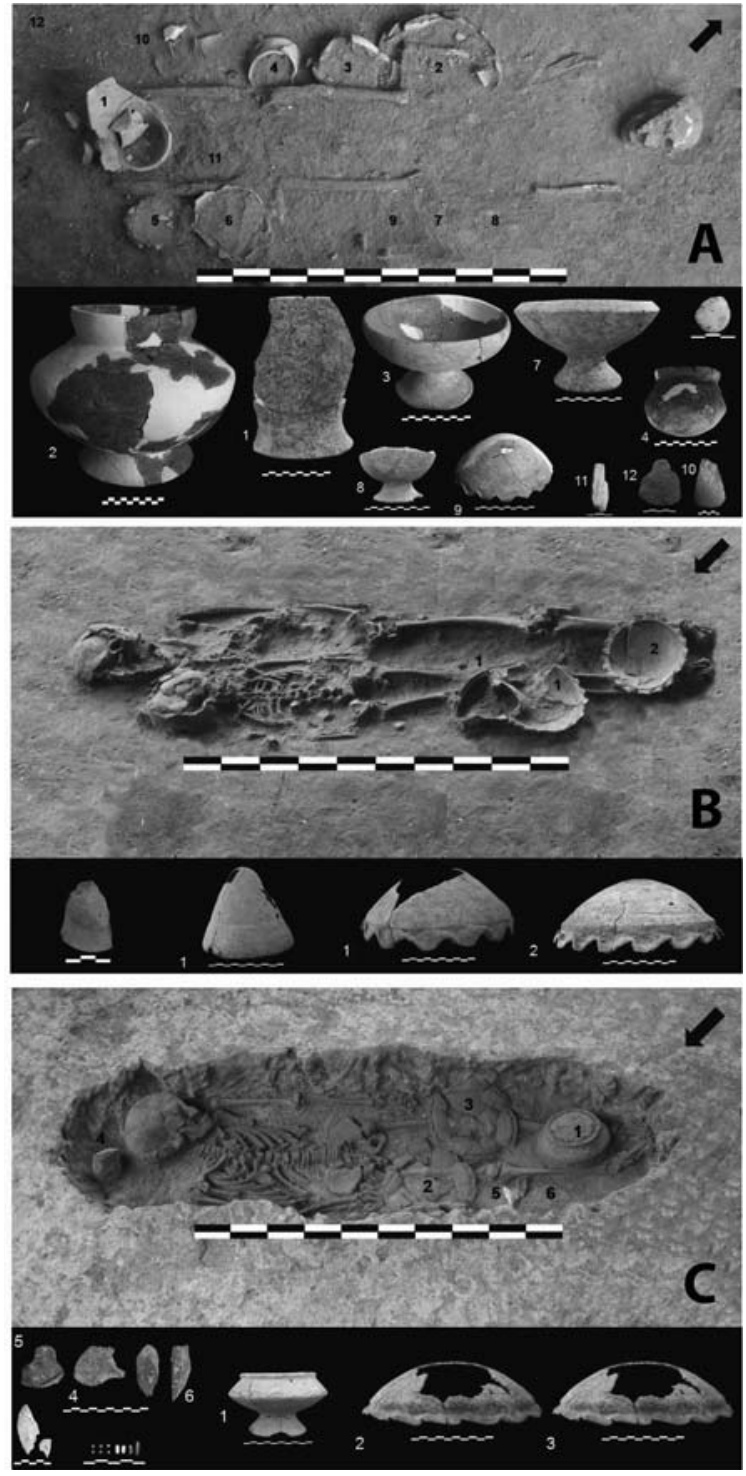

Fig. 10. Three supine extended burials with associated grave goods excavated at An Son in 2009. Black arrows point north. Photos prepared by Anna Willis.

a. Trench 1 burial 2, dated to 13971267 B.C. (NZA 34172).

b. Trench 1 , burials 3 and 4 , dated to 1431-1314 B.C. for the adult burial 3 (NZA 34173).

c. Trench 2, burial 3, dated to $1262-$ 1057 B.C. (NZA 34174). Only one of the wavy rimmed vessels from this grave has been restored, so it is shown twice for illustrative purposes.

Trench 2, Burial 2, Not AMS Dated. Infant <1Year, Oriented Northeast/Southwest - This neonate was almost complete, but the cranium had been crushed and there was some disturbance to the postcranial skeleton. There was a small vertically cord-marked restricted vessel with an everted rim associated with this individual. Two cylindrical shell beads were found in the chest area.

Trench 2, Burial 3, Dated by NZA 34174 to 1262-1057 B.C. Adolescent 10-14 Years, Oriented Northeast/Southwest - This adolescent is complete and very well preserved, with three pots (Fig. 10c). Two of these were wavy-rimmed open bowls, one over the right femur and hand, a second over the left distal femur and proximal tibia. A footed 
and carinated bowl was also placed between the tibiae and calcanii. There was also a shouldered adze beside the right proximal tibia, 13 disc-shaped and cylindrical shell beads in the chest area, and other pieces of stone and shell that could have been grave goods.

\section{The Biological Affinities of the An Son Population}

A multivariate analysis of cranial and dental metric data and an assessment of the morphometric affinities of the An Son mortuary assemblage gave interesting results, to be reported in detail elsewhere. Cranial metrics indicate affinities with the Bronze-Iron Age Dong Son population of northern Vietnam and with modernVietnamese, as well as with other modern East Asians, while dental metric comparisons point to similarities with earlier Holocene Jomon and Hoabinhian populations. This suggests that the An Son people preserved some genetic traits of earlier Southeast Asian indigenous populations, but were also derived from a process of migration from other regions of East Asia. However, the inconsistency between the cranial and dental data from An Son might also reflect sample bias, in which the dental remains have been more utilized for study than the poorly preserved skulls, or it might reflect different patterns of inheritance between cranial and dental metrics. Certainty will require a larger sample of crania.

The general conclusion on the affinities of the An Son crania is in accord with the "Two-Layer" model of Holocene population history in Southeast Asia (Matsumura 2006; Matsumura and Hudson 2005; Matsumura et al. 2008a, 2008b), based on the analysis of dental traits and on skeletal evidence uncovered from Vietnam, Malaysia, and Thailand. Several cases of population change through admixture with more northerly Asian populations are especially evident at the site of Man Bac in northern Vietnam, where some of the cranial and dental traits exhibited by the early indigenous Hoabinhian people continued to be expressed into the middle Holocene. But these pre-Neolithic people, especially the Da But culture skeletons from Con Co Ngua (c. 3000 B.C.), display large morphological differences with the early Metal Age Dong Son people (c. 2000 B.P.) (Matsumura et al. 2008a).

\section{THE AN SON SUBSISTENCE ECONOMY}

In total, 8610 animal bones were recovered from 2009 Trench 2 and the test pit through wet sieving using $2 \mathrm{~mm}$ sieves (Table 3) (Piper et al. 2012). Of these, 2829 $(32 \%)$ were the skeletal remains of terrestrial mammals and reptiles, and 6077 (68\%) were fish bones. All in all, 1356 (47.8\%) fragments of mammal and reptile and 274 (4.5\%) fragments of fish could be identified to family or a higher taxonomic level. This assemblage was supplemented by biometrical and age at death data from fragments of pig and cranial and postcranial elements hand collected from Trench 1.

The mammal assemblage was dominated by remains of pig and dog. The oldest pig remains were recovered from the test pit at a depth of $230-240 \mathrm{~cm}$ and correspond with a date of 2862-2234 B.C. (ANU 9709-Table 1). Trench 2 produced 83 suid fragments and, combined with pieces of mandible from Trench 3, a minimum of 6 individuals from 16 partial mandibles and loose lower teeth (P4-M3) could be identified. Five specimens (4 individuals) still retained $d p 4 s$ in various stages of wear. 
TAble 3. The Number of IDENTIFIEd SPeCimens (NISP) OF DifFerent Vertebrate taXa RECOVERED FROM AN SON

\begin{tabular}{|c|c|c|c|c|c|}
\hline CLASS & ORDER & FAMILY & TAXON & COMMON NAME & NISP \\
\hline \multirow[t]{17}{*}{ Actinopterygii } & Clupeiformes & Clupeidae & & Shad & 4 \\
\hline & & Engraulidae & & Thryssa & 3 \\
\hline & Cypriniformes & Cyprinidae & & Carps & 3 \\
\hline & Siluriformes & Bagridae & & Asian river catfish & 7 \\
\hline & & Siluridae & Wallago attu & White sheat fish & 8 \\
\hline & & Pangasiidae & & Shark catfish & 3 \\
\hline & & Clariidae & & River catfish & 17 \\
\hline & Beloniformes & Belonidae & & Needlefish & 2 \\
\hline & Synbranchiformes & Synbranchidae & & Swamp eel & 65 \\
\hline & & Mastacembelidae & & Tire track eel & 14 \\
\hline & Perciformes & Centropomidae & Lates calcarifer & Barramundi & 13 \\
\hline & & Chandidae & & Glassy perchlets & 10 \\
\hline & & Nandidae & Pristolepis fasciata & Catopra & 2 \\
\hline & & Eleotridae & & Sleepers & 3 \\
\hline & & Anabatidae & Anabas testudineus & Climbing perch & 53 \\
\hline & & $\begin{array}{c}\text { Osphronemidae: } \\
\text { Belontiinae }\end{array}$ & Belontia sp. & Gourami & 1 \\
\hline & & Channidae & & Snakehead & 66 \\
\hline \multirow[t]{7}{*}{ Reptilia } & Testudines & Geoemydidae & & $\begin{array}{l}\text { Pond, box and } \\
\text { water turtles }\end{array}$ & 1070 \\
\hline & & & Cuora $\mathrm{sp}(\mathrm{p})$ & Box turtle & 4 \\
\hline & & & Cyclemys dentata & Asian leaf turtle & 2 \\
\hline & & & $\begin{array}{l}\text { cf. Hieremys } \\
\text { annandalii }\end{array}$ & $\begin{array}{l}\text { Yellow-headed } \\
\text { temple turtle }\end{array}$ & 1 \\
\hline & & Trionychidae & & Soft-shell turtles & 7 \\
\hline & Squamata & Varanidae & Varanus cf. salvator & Monitor lizard & 40 \\
\hline & Crocodylia & Crocodylidae & $\begin{array}{l}\text { Crocodylus cf. } \\
\text { porosus }\end{array}$ & $\begin{array}{l}\text { Saltwater } \\
\quad \text { crocodile }\end{array}$ & 12 \\
\hline \multirow[t]{8}{*}{ Mammalia } & Primates & Cercopithecidae & & $\begin{array}{l}\text { Old world } \\
\text { monkeys }\end{array}$ & 3 \\
\hline & Rodentia & Muridae & Rattus $\mathrm{sp}(\mathrm{p})$. & rat (commensal) & 5 \\
\hline & Carnivora & Canidae & $\begin{array}{l}\text { Canis lupus } \\
\text { familiaris }\end{array}$ & Domestic dog & 109 \\
\hline & & Viverridae & & Civet cat & 1 \\
\hline & Artiodactyla & Suidae & $\begin{array}{l}\text { Sus scrofa } \\
\quad \text { (domestic) }\end{array}$ & Domestic pig & 83 \\
\hline & & Tragulidae & Tragalus napu & Mouse deer & 3 \\
\hline & & Cervidae & Muntiacus $\mathrm{sp}(\mathrm{p})$ & Muntjac & 2 \\
\hline & & & Cervus/Rusa sp(p). & Deer & 14 \\
\hline
\end{tabular}

Another loose lower right dp4 still had roots, indicating that it had not been naturally shed. Overall, none of the specimens (mandibular or maxillary) recovered would appear to have exceeded 18 months to 2 years of age, with most slaughtered within the first 12 months of life. The age profile derived from the dentition is supported by a predominance of postcranial elements with unfused articular ends, from juvenile individuals. The predominance of juvenile and subadult pigs in the assemblage suggests that this represents a managed, domestic population. Most of the pig remains were recovered from the "rake-out" deposits in Trench 2, and although pigs are present 
from the earliest phases of occupation recorded in the 2009 excavations they cannot be clearly identified as domestic until after 2000 B.C. because of small sample sizes.

The earliest evidence of $\mathrm{dog}$ is from the test pit at 190-200 cm. These remains are slightly above the 2862-2234 B.C. radiocarbon date. Combining right mandibular fragments from Trenches 2 and 3, at least five adult individuals are recorded. All appear to have had fully erupted and in wear M1s and/or M2s, though none of the individuals appears to have reached a substantial age, judging from the limited reduction in occlusal surfaces. The distal shaft of a right humerus with an unfused articular end indicates that at least one subadult individual is also represented in the assemblage.

Cut marks on the antero-medial surface of the distal end of a right tibia, the antero-medial aspect of a right humerus, and along the cranial margins of a mandibular ramus indicate that dogs were being butchered and presumably eaten. The dog bones were recovered from within the general site refuse, with no evidence of any variation in discard patterns that would suggest any conscious human differentiation between dogs and other food animals.

An interesting taphonomic feature of the An Son animal bone assemblage is the absence of dog-gnawed and digested bone and the presence of large numbers of wellpreserved fish bones. This contrasts markedly with the Late Neolithic and Early Metal Age layers at Nagsabaran in northern Luzon, where dog gnawing is evident, even though dog remains are much less common than at An Son. It is possible the dogs at An Son were not free ranging but tethered or corralled, and thus not allowed access to scavenging around this part of the settlement.

The most common terrestrial wild vertebrates are the carapace and plastra of turtles (Testudines, $n=1076$ ), predominantly of the family Geoemydidae (pond, box, and water turtles). At least 16 individuals (based on the right hypoplastra) and 3 taxa could be initially identified (Table 3) in this study-box turtles (Cuora sp[p].), Asian leaf turtles (Cyclemys dentata), and possibly the yellow-headed temple turtle (Hieremys annandalii), but more species are likely to be represented. Further research has also identified the river terrapin (Batagur $\mathrm{cf}$. baska). In addition there were small numbers of deer bones (Cervus/Rusa sp[p].), monitor lizard (Varanus sp[p].), the mouse deer (Tragalus napu), crocodile (Crocodylus cf. porosus), the large Indian civet (Viverra zibetha) or large-spotted civet (Viverra megaspila), and monkey (Cercopithecidae), but all in small numbers, suggesting they did not constitute a large proportion of the diet.

The most abundant zooarchaeological remains recovered at An Son were fish $(n=6077)$. There was a strong predominance of cranial fragments (some still articulated) in the collection, suggesting that the hard bony-plated heads were removed prior to consumption and discarded. Provisionally, 17 different families were recorded (Table 3), with the most common being the snakehead (Channidae), swamp eel (Synbranchidae), and climbing perch (Anabas testudineus). Other taxa identified included river catfish (Clariidae), Barramundi (Centropomidae), tire track eels (Mastacembelidae), and glassy perchlets (Chandidae). A range of techniques are used to catch these fish by modern communities including hook and line, push nets, gill nets, specialized traps, and seines. For example, the swamp eel can be trapped using a bamboo tube trap or speared with an eel fork (Voeun 2006).

The faunal remains suggest a subsistence economy based on the management of domestic pigs and dogs and a strong focus on fishing within local rivers, supplemented with the hunting of a range of terrestrial and aquatic mammals and reptiles. 
Three artifacts manufactured from animal bone are of note. A small curved fragment of elephant ivory $42.9 \mathrm{~mm}$ long (identification confirmed by Sonia O'Connor, University of Bradford) has a high surface polish and probably represents the partial remains of something like an armband. Two male pig lower right tusks have been deliberately modified at the caudal end through grinding on the occlusal and mesial surfaces to thin them. On both, the cranial end has been ground flat through use as some sort of tool or abrader. Adhering to the buccal surface of one there are three patches of resinous material, the largest being more than $10 \mathrm{~mm}$ in length. It is possible that this was applied to fix a haft to the caudal end of the canine.

It should be reiterated that An Son contains no evidence for maritime subsistence, implying that the site was well inland at the time of its initial occupation. Large bivalves of the soft shore estuarine species variously termed Geloina, Batissa, or Polymesoda do occur singly here and there in the deposits, many with clear signs of abrasion on their sharp distal edges. Presumably they were used as tools, possibly harvesting knives, hence imported specially for task rather than food purposes. Otherwise, the 2009 excavation yielded almost exclusively the mangrove gastropod Cerithidea obtusa, occurring at densities of up to 4152 shells per cubic meter of excavated deposit in Trench 2. These served as food, with extraction involving heating or boiling and breakage of the shell apex to "breach the vacuum" and allow withdrawal of the soft body.

\section{The An Son Rice}

Two samples of rice husk used as pottery temper were analyzed in the Ancient DNA laboratory in the Research Institute of Humanity and Nature in Kyoto. The analytical details will be published in detail elsewhere, but a gene coding region within chloroplast DNA was studied by Katsunori Tanaka and Yo-ichiro Sato using PCR (polymerase chain reaction) amplification to reveal that both samples were of Oryza sativa japonica, the subspecies domesticated in the Yangzi Basin in China, rather than Oryza sativa indica, the subspecies native to India and Southeast Asia (Fuller et al. 2010; Londo et al. 2006). The two samples came from middle layers of the 2009 Trench 1 at An Son, and date to about 1500 B.C. At present it is not clear if rice was present from the absolute beginning of the An Son occupation, particularly from the base of the 1997 trench (Nishimura and Nguyen 2002:104). However, the 2009 excavations recovered evidence for rice husks in pottery to the base of the areas then excavated (SEM analyses by Carmen Sarjeant). Furthermore, phytolith analysis of the basal layers of 2009 Trench 2 and the 2009 test pit, by Melissa Tan of the Institute of Archaeology, London, and by Tetsuro Udatsu of Miyazaki University in Japan, have revealed the presence of definite rice phytoliths (results to be published separately).

\section{CONCLUSIONS}

The research described above was undertaken as part of a larger project, funded by the Australian Research Council, entitled "The creation of Southeast Asian peoples and cultures, 3500 BC to AD 500." The aim of this project has been to understand the arrival of Neolithic assemblages across northern regions of Southeast Asia, especially in Vietnam and the Philippines, in terms of relationships with contemporary and earlier Neolithic developments in southern China and Taiwan (see, for example, Bell- 
wood and Dizon 2008; Oxenham et al. 2011; Bellwood 2011). This report provides detailed information on the oldest Neolithic developments discovered so far in southern Vietnam, specifically at the site of An Son. The assemblage from here, dated back into the late third millennium B.C., commenced with a thin layer from which economic evidence is at present lacking. Indeed, the full cultural content of layer 3.5 at the base of the main mound, dug in 1997 but not clearly intersected in 2009, will need to be resolved by further excavation. The question remains of whether or not the base of the site as exposed in 1997 housed an ephemeral cultural phase that lacked evidence for pig domestication and possibly also rice cultivation. Similar economic absences are claimed also for the basal Neolithic layers in the sites of Nong Nor and Khok Phanom Di in central Thailand (Higham and Thosarat 1998; 2004).

By at least 1800 B.C. there is evidence for food production at An Son, based on japonica rice, domesticated pigs and dogs, and associated exploitation of riverine and estuarine (not marine) resources. The material culture, associated with supine extended burials (none flexed), includes pottery, some rice chaff tempered, and a range of cut and ground items of stone and shell. Flaked lithics are noticeably absent, and there is no sign of any archaeological continuity from putative Hoabinhian antecedents.

The An Son assemblage has some quite distinctive local features, such as the common wavy- and serrated-rimmed pottery vessels that first developed above the basal layers in the site. It also has many aspects of pottery decoration and artefact shape that link it with contemporary assemblages in central and northeastern Thailand. We can point briefly in this regard to Khok Phanom Di (shouldered adzes, shell disc beads, bone fishhooks, incised and punctate pottery, supine burials, and rice) and Ban Non Wat (similar to the above, with the addition of pottery discs, baked clay bow pellets, and absence of bangles and spindle whorls until after the Neolithic) (Higham and Thosarat 2004; Higham and Kijngam 2009, 2010). Specific parallels relating to the earliest phases of occupation at An Son, Nong Nor and Khok Phanom Di have been noted in the section on pottery. Such parallels could be multiplied to cover many Neolithic sites in Thailand. However, it is our impression that parallels between An Son and Neolithic northern Vietnam (e.g., with Phung Nguyen related sites such as Man Bac in Ninh Binh Province-Oxenham et al. 2011) are fewer than those with sites in the Mekong drainage system in general, including central Thailand.

This is not the place to examine such patterns of relationship in greater detail (Rispoli 2007 covers some of the ground), but the apparently close relationship between the Neolithic assemblages of southernVietnam and the greater Mekong region is interesting. They could suggest a source for the An Son facies of the mainland Southeast Asian Neolithic more to the northwest than to the direct north, in southern Chinese terms perhaps more strongly with Yunnan via the Mekong rather than with Guangxi or Guangdong. But at present such observations are impressionistic, and they need to be founded on much more detailed research and comparison. The strongest observation that can be made at present is that signs of archaeological continuity from the pre-Neolithic in southern Vietnam are totally lacking, so the complex as a whole was surely introduced from another region.

In biological terms, this brings up the issue of the "two-layer" population hypothesis, as discussed above for the An Son skeletal remains. This hypothesis has gained theoretical support from historical linguistics and archaeology, which have linked the ancestral dispersals of especially the Austronesian, Austroasiatic, Daic (Tai-Kadai), and Sino-Tibetan (Tibeto-Burman) language families with the expansion of 
food-producing populations from central and southern China during the Neolithic (Bellwood 1997, 2005, 2013; Blust 1996; Higham 2011; Higham and Thosarat 2004; Zhang and Hung 2010). With the exception of Sino-Tibetan, which also spread to the north and west, these language families expanded primarily to the south, including Austronesian from Taiwan. The two-layer hypothesis for mainland Southeast Asia is therefore founded upon a Hoabinhian biological population base (with cultural continuity receiving little support in southern Vietnam at present), with significant in-migration of intrusive populations from other regions, predominantly to the north or northwest. These incoming Neolithic populations surely had a number of different origins across mainland Southeast Asia as a whole, especially when viewed from the perspectives of the present distributions of the Daic and Austroasiatic language families (Bellwood 2005; Sidwell 2013). The site of An Son could be informative from an Austroasiatic origins perspective.

\section{ACKNOWLEDGMENTS}

The 2009 season of excavation at An Son was funded by the Australian Research Council, Discovery Project Grant DP0774079, to Peter Bellwood, Marc Oxenham, and Janelle Stevenson. We wish to thank Bui Phat Diem, Director of the Long An Museum in Tan An City, and Vice-Director Vuong Thu Hong, for giving permission for the research to proceed.

In the collection of data and the writing of this report, the following contributions are noted:

Peter Bellwood, Marc Oxenham, Bui Chi Hoang, and Nguyen Kim Dzung: organization and direction of the 2009 excavation and postexcavation analysis;

Anna Willis: burial analysis;

Carmen Sarjeant: pottery analysis;

Philip Piper, Fredeliza Campos, Dang Ngoc Kinh, and Noel Amano: animal bones; Hirofumi Matsumura and Nguyen Lan Cuong: cranial analysis;

Katsunori Tanaka and Yo-Ichiro Sato: rice DNA analysis;

Nguyen Quoc Manh, Nguyen Khanh Trung Kien, Vo Thanh Huong, Van Ngoc Bich, Tran Thi Kim Quy, and Nguyen Phuong Thao: postexcavation artifact analysis;

Nancy Beavan, and Tom Higham: radiocarbon dating and analysis; and

Nguyen Kim Dung and Masanari Nishimura: information on the 1997 excavation at An Son.

We wish to thank Stewart Fallon of the SSAMS Radiocarbon Dating Centre (ANU, Canberra, Australia) for provision of radiocarbon dates. Valuable comments on the manuscript were provided by Charles Higham, Andreas Reinecke, and Masanari Nishimura. Sonia O'Connor (Archaeological Science, University of Bradford) confirmed the 2009 discovery of a piece of elephant ivory.

\section{REFERENCES CITED}

Bellwood, Peter

1997 Prehistory of the Indo-Malaysian Archipelago, revised ed. Honolulu: University of Hawai'i Press. 2005 First Farmers. Oxford: Blackwell.

2011 Holocene population history in the Pacific region as a model for world-wide food producer dispersals. Current Anthropology 52, No. S4:363-378. 
2013 First Migrants: Ancient Migration in Global Perspective. Oxford and Malden, Mass.: WileyBlackwell.

Bellwood, Peter, and Eusebio Dizon

2008 Austronesian cultural origins: out of Taiwan, via the Batanes Islands, and onwards to western Polynesia, in Past Human Migrations in East Asia: Matching Archaeology, Linguistics and Genetics: 23-39, ed. A. Sanchez-Mazas, R. Blench, M. Ross, I. Peiros, and M. Lin. London: Routledge.

Blust, Robert A.

1996 Beyond the Austronesian homeland: The Austric hypothesis and its implications for archaeology, in Prehistoric Settlement of the Pacific: 117-140, ed. W. H. Goodenough. Philadelphia: American Philosophical Society.

Bronk Ramsey, C.

2009 Bayesian analysis of radiocarbon dates. Radiocarbon 51(1):337-360.

Bui Phat Diem, Vuong Thu Hong, and Masanari Nishimura

1997 Research achievements of the archaeology before "Oc Eo Culture" in the lowerVam Co river basin. Journal of Southeast Asian Archaeology 17:72-77.

Buikstra, E. Jane, and Douglas H. Ubelaker

1994 Standards for Data Collection from Human Skeletal Remains: Proceedings of a Seminar at the Field Museum of Natural History. Fayetteville: Arkansas Archaeological Survey.

CAMERon, JUdith

2002 Textile Technology in the Prehistory of Southeast Asia. Unpublished Ph.D. thesis, Australian National University, Canberra.

Dang Van Thang, Bui Phat Diem, Vuong Thu Hong, Van Nhoc Bich, Nguyen Phyong Thao, Do

Thi Lan, and Tran Thi Kim Quy

2008 Report on the Excavation of Archaeological Remains from An Sơn, Loc Giang, Dong Canh Nong, Go Xoai: Duc Hoa district, Long An province. Tan An: Bao Tang Long An (unpublished report, in Vietnamese).

Fuller, Dorian, Yo-chiro Sato, Christine Castillo, Ling Qin, Alison. R. Weisskopf, Eleanor J. Kingwell-Banham, Jixiang Song, Sung-Mo Ahn, and Jacob van Etten

2010 Consilience of genetics and archaeobotany in the entangled history of rice. Archaeological and Anthropological Science 2:115-131.

Gilligan, Ian

2010 The prehistoric development of clothing: Archaeological implications of a thermal model. Journal of Archaeological Method and Theory 17:15-80.

Green, F. J.

1979 Phosphatic mineralization of seeds from archaeological sites. Journal of Archaeological Science 6(3): $279-284$.

Hedges, R., J. Lee-Thorp, and N. Tuross

1995 Is tooth enamel carbonate a suitable material for radiocarbon dating? Radiocarbon 37 , No. $2: 285-290$.

Higham, Charles

2010 Summary and conclusions, in The Origins of the Civilization of Angkor, vol. 4: The Excavation of Ban Non Wat: The Neolithic Occupation: 199-211, ed. C. Higham and A. Kijngam. Bangkok: Thai Fine Arts Department.

Higham, Charles, and Thomas Higham

2009 A new chronological framework for prehistoric Southeast Asia, based on a Bayesian model from Ban Non Wat. Antiquity 83:125-144.

Higham, Charles, and Amphan Kijngam, eds.

2009 The Excavation of Ban Non Wat. Part One: Introduction. Bangkok: Thai Fine Arts Department.

2010 The Excavation of Ban Non Wat. Part Two: The Neolithic Occupation. Bangkok: Thai Fine Arts Department (The Origins of the Civilization of Angkor, vol. 4).

Higham, Charles, and Rachanie Thosarat

2004a The Excavation of Khok Phanom Di., vol. 7: Summary and Conclusions. London: Society of Antiquaries.

Higham, Charles, and Rachanie Thosarat, eds.

1998 The Excavation of Nong Nor. Dunedin: University of Otago Studies in Prehistoric Anthropology 18. 
$2004 b$ The Excavation of Ban Lum Khao. Bangkok: Thai Fine Arts Department (The Origins of the Civilization of Angkor, vol. 1).

Higham, Charles, and Warrachai Wiriyaromp

2010 Neolithic 1 ceramic motifs, in The Origins of the Civilization of Angkor, vol. 3: The Excavation of Ban Non Wat. Part Two: The Neolithic Occupation: 93-106, eds C. Higham and A. Kijngam. Bangkok: Thai Fine Arts Department. (The Origins of the Civilization of Angkor, Volume 4).

Kuczumow, A., E. Cukrowska, A. Stachniuk, R. Gaweda, R. Mroczka, W. Paszkowicz, K. Skrzypiec, R. Falkenberg, and L. Backwell

2010 Investigation of chemical changes in bone material from South African fossil hominid deposits. Journal of Archaeological Science 37(1): 107-115.

LeE-Thorp, Julia

2000 Preservation of biogenic carbon isotope signals in Plio-Pleistocene bone and tooth mineral, in Biogeochemical Approaches to Paleodietary Analysis: 89-115, ed. S. Ambrose and M. Katzenberg. New York: Kluwer Academic/Plenum Press.

LeE-Thorp, Julia, And Matt Sponheimer

2003 Three case studies used to reassess the reliability of fossil bone and enamel isotope signals for paleodietary studies. Journal of Anthropological Archaeology 22 : 208-216.

Liversidge, H. M., M. C. Dean, and T. I. Molleson

1993 Increasing human tooth length between birth and 5.4 years. American Journal of Physical Anthropology 90(3):307-313.

Londo, Jason, Yu-Chung Chiang, Kuo-Hsiang Hung, Tzen-Yuh Chiang, and Barbara Schaal

2006 Phylogeography of Asian wild rice, Oryza rufipogon. Proceedings of the National Academy of Sciences 103:9578-9583.

MALLERET, LOUIS

1963 L'Archeologie du delta du Mekong, tome quatrieme (The Archaeology of the Mekong Delta, volume 4), Le Cisbassac. Paris: EFEO.

Matsumura, Hirofumi

2006 The population history of Southeast Asia viewed from morphometric analyses of human skeletal and dental remains, in Bioarchaeology of Southeast Asia: 33-58, ed. M. Oxenham and N. Tayles. Cambridge: Cambridge University Press.

Matsumura, Hirofumi, and Mark Hudson

2005 Dental perspectives on the population history of Southeast Asia. American Journal of Physical Anthropology $127: 182-209$.

Matsumura, Hirofumi, Marc Oxenham, Yukio Dodo, Kate Domett, Nguyen Kim Thuy, Nguyen

Lan Cuong, Nguyen Kim Dung, Damien Huffer, and Mariko Yamagata

2008a Morphometric affinity of the late Neolithic human remains from Man Bac, Ninh Binh Province, Vietnam: Key skeletons with which to debate the "two layer" hypothesis. Anthropological Science 116:135-148.

Matsumura, Hirofumi, Minoru Yoneda, Yukio Dodo, Marc F. Oxenham, Nguyen Lan Cuong, Nguyen Kim Thuy, Lam My Dung, Vu The Long, Mariko Yamagata, Junmei Sawada, Kenichi ShiNODA, AND WaTARU TAKigaWA

$2008 b$ Terminal Pleistocene human skeleton from Hang Cho cave, northern Vietnam: Implications for the biological affinities of Hoabinhian people. Anthropological Science 116:201-217.

Nguyen Kim Dung, and M. Yamagata et al.

2011 The Man Bac burial pottery, in Terra Australis vol. 33: Man Bac: The Excavation of a Neolithic Site in Vietnam, pp. 169-85, eds M. Oxenham, H. Matsumura and Nguyen Kim Dung. Canberra: ANU E Press.

NGUYen, LAN CUONG

2005 Report on the human skeletal remains of the ancient site of An Son, Long An, third excavation. Tan An: Bao Tang Long An (unpublished report, in Vietnamese).

Nguyen, Van Lap, Thi K. Ta, and Masaaki Tateishi

2000 Late Holocene depositional environments and coastal evolution of the Mekong River Delta. Journal of Asian Earth Sciences 18: 427-439.

Nishimura, Masanari

2002 Chronology of the Neolithic age in southern Vietnam. Journal of Southeast Asian Archaeology $22: 25-57$. 
Nishimura, Masanari, and Nguyen Kim Dung

2002 Excavation of An Son: A Neolithic mound site in the middle reach of the Vam Co Dong river, southern Vietnam. Bulletin of the Indo-Pacific Prehistory Association 22:101-109.

Nishimura, Masanari, Nguyen Duy Ty, and Nguyen Xuan Ly

2009 The Excavation of Da Kai: A Neolithic Circular Settlement Site in the Upper Reach of the Dong Nai River, Southern Vietnam. Southeast Asian Archaeology Data Monograph No. 1. Yamaguchi, Japan: Foundation to Safeguard the Underground Cultural Heritage in Southeast Asia.

Nishimura, Masanari, and Vuong Thu Hong

1997 Preliminary study on the pottery decoration in the Vam Co River Basin. Journal of Southeast Asian Archaeology 17:78-90.

O'Reilly, Dougald

1998 The ceramic analysis, in The Excavation of Nong Nor: 97-119, ed. C. Higham and R. Thosarat. Dunedin: University of Otago Studies in Prehistoric Anthropology 18.

2004 Ceramic categorisation and description, in The Excavation of Ban Lum Khao: 231-7, ed. C. Higham and R. Thosarat. Bangkok: Thai Fine Arts Department.

OXenham, MarC

2000 Heath and Behaviour during the Mid-Holocene and Metal Period of Northern Viet Nam. Unpublished Ph.D. thesis. Northern Territory University, Darwin, Australia.

Oxenham, Marc, Hirofumi Matsumura, and Nguyen Kim Dung

2011 Man Bac: The Excavation of a Neolithic Site in Northern Vietnam. Canberra: Australian National University E Press.

Pham Quang Son, Nguyen Quoc Manh, Nguyen Thi Haoi Huong, and Nguyen Thi Tuyet Trinh 2006 Report on the archaeological excavation of An Son, An Ninh Tay village, Duc Hoa district, Long An province. Tan An: Bao Tang Long An (unpublished report, in Vietnamese).

Phenice, T. W.

1969 A newly developed visual method of sexing the 0s pubis. American Journal of Physical Anthropology 30:297-301.

Piga, G., A. Santos-Cubedo, S. Moya Solà, A. Brunetti, A. Malgosa, and S. Enzo

2009 An X-ray Diffraction (XRD) and X-ray Fluorescence (XRF) investigation in human and animal fossil bones from Holocene to Middle Triassic. Journal of Archaeological Science 36 : 18571868.

Piper, Philip, Fredeliza Campos, Dang Ngoc Kinh, Marc Oxenham, Bui Chi Hoang, Peter BellWOOD, AND ANNA WILLIS

2012 Early evidence for pig and dog husbandry from the site of An Son, Southern Vietnam. International Journal of Osteoarchaeology: (advance online DOI: 10.1002/oa.2226).

Proske, Ulrike, Till Hanebuth, Hermann Behling, Van Nguyen, Thi K. O. Ta, and Bui Diem

2010 The palaeoenvironmental development of the northeastern Vietnamese Mekong River Delta since the mid Holocene. The Holocene 20:1257-1268.

Quang Van Cay and Ngo The Phong

1994 Report on the archaeological excavation at Loc Giang, Duc Hoa district, Long An Province. Hanoi:Vien Bao Tang Lich Su Viet Nam and Tan An: Long An Museum (unpublished report, in Vietnamese).

Reimer, P. J., M.G.L. Baillie, E. Bard, A. Bayliss, J. W. Beck, P. G. Blackwell, C. Bronk Ramsey, C. E. Buck, G. Burr, R. L. Edwards, M. Friedrich, P. M. Grootes, T. P. Guilderson, i. Hajdas, T. J. Heaton, A. G. Hogg, K. A. Hughen, K. F. Kaiser, B. Kromer, F. G. McCormac, S. W. Manning, R. W. Reimer, D. A. Richards, J. R. Southon, S. Talamo, C.S.M. Turney, J. van der Plicht, and C. E. WeyHENMEYER

2009 Intcal09 and Marine09 radiocarbon age calibration curves, 0-50,000 years cal BP. Radiocarbon 51(4): 1111-1150.

Rispoli, Fiorella

1992 Preliminary report on the pottery from Tha Kae, Lopburi, central Thailand, in Southeast Asian Archaeology, Proceedings of the Third Conference of the European Association of Southeast Asian Archaeologists: 129-142, ed. I. Glover. Hull: Centre for South-East Asian Studies.

1997 Late third-mid second millennium BC pottery traditions in central Thailand: Some preliminary observations in a wider perspective, in South-East Asian Archaeology 1992: Proceedings of the Fourth International Conference of the European Association of the South-East Asian Archaeologists: 59-97, ed. R. Ciarla and F. Rispoli. Rome: Instituto Italiano per l'Africa e L'Oriente. 
2007 The incised and impressed pottery style of mainland Southeast Asia: Following the paths of Neolithisation. East and West $57: 235-304$.

Rissech, Carme, Maureen Schaefer, and Assumpció' Malgosa

2008 Development of the femur-implications for age and sex determination. Forensic Science International 180:1-9.

SARJEANT, CARMEN

2012a The Role of Potters at Neolithic An Son, Southern Vietnam. Unpublished PhD thesis, Australian National University.

$2012 b$ Defining the Neolithic of southern Vietnam: the ceramics of An Son, in Crossing Borders: Selected Papers from the 13th International Conference of the European Association of Southeast Asian Archaeologists, vol. 1, eds D. Bonatz et al. Singapore: National University of Singapore.

SCOTT, E. C.

1979 Dental wear scoring technique. American Journal of Physical Anthropology 51:213-217.

Shepard, AnNa O.

1964 Ceramics for the Archaeologist. Washington, DC: Carnegie Institution, Publication 609.

Sidwell, Paul

2013 Southeast Asian mainland: linguistic history, in Encyclopedia of Global Human Migration, vol. 1: Prehistory: 259-68, eds I. Ness, I. and P. Bellwood. Malden (Massachusetts, USA) and Oxford: Wiley-Blackwell.

Sponheimer, Matt, and Julia A. Lee-Thorp

1999 The alteration of enamel carbonate environments during fossilisation. Journal of Archaeological Science 26:143-150.

Ta, Thi K., Van Lap Nguyen, Masaaki Tateishi, Iwao Kobayashi, Susumu Tanabe, and Yoshiko SAITO

2002 Holocene delta evolution and sediment discharge of the Mekong River, southern Vietnam. Quaternary Science Reviews $21: 1807-1819$.

Tocheri, M. W., T. L. Dupras, P. Sheldrick, and J. E. Molto

2005 Roman period fetal skeletons from the east cemetery (Kellis 2) of Kellis, Egypt. International Journal of Osteoarchaeology 15(5):326-341.

Tomber, Roberta, Caroline Cartwright, and Sunil Gupta

2011 Rice temper: Technological solutions and source identification in the Indian Ocean. Journal of Archaeological Science 38:360-366.

Ubelaker, Douglas H.

1989 Human Skeletal Remains: Excavation, Analysis, Interpretation. Washington, DC: Taraxacum.

Van Ngoc Bich, Do Thi Lanh, and Nguyen Phuong Thao

20082007 excavations at An Son. Tan An: Bao Tang Long An (unpublished report, in Vietnamese).

VINCENT, BRIAN

2004 The Excavation of Khok Phanom Di., Vol. 6: The Pottery. London: Society of Antiquaries.

Voeun, Vuthy

2006 Osteological Guide of Fishes from the Mekong System in Cambodia. Phnom Penh: Cambodia.

Walrath, E. Dana, Paul Turner, and Jaroslav Bruzek

2004 Reliability test of the visual assessment of cranial traits for sex determination. American Journal of Physical Anthropology $125: 132-137$.

WANG, Y., AND T. E. CERLING

1994 A model for fossil tooth and bone diagenesis: Implications for paleodiet reconstruction from stable isotopes. Palaeogeography, Palaeoclimatology, Palaeoecology 107:596-606.

Woodman, Neil, and Nancy Beavan-Athrield

2009 Post-Clovis survival of American mastodon in the southern Great Lakes region of North America. Quaternary Research 72:359-363.

Zazzo, A., AND J.-F. SAli'ege

2010 Radiocarbon dating of biological apatites: A review. Palaeogeography, Palaeoclimatology, Palaeoecology (10.1016/j.palaeo.2010.12.004).

Zhang Chi AND HSIAO-Chun Hung

2010 The emergence of agriculture in southern China. Antiquity 84:11-25. 


\section{ABSTRACT}

Between 4500 and 3500 years ago, partially intrusive Neolithic populations in the riverine basins of mainland Southeast Asia began to form mounded settlements and to develop economies based on rice cultivation, fishing, hunting, and the domestication of animals, especially pigs and dogs. A number of these sites have been excavated in recent years and they are often large mounds that can attain several meters in depth, comprising successive layers of alluvial soil brought in periodically to serve as living floors. The site of An Son is of this type and lies in a small valley immediately north of the Mekong Delta in southern Vietnam. Excavated on five occasions since 1978, and most recently in 2009, it was occupied from the late third into the late second millennium B.C. An Son has produced evidence that attests the domestication of pigs and dogs in all layers apart (perhaps) from the most basal one, which was not investigated in 2009, together with the growing of rice of the subspecies Oryza sativa japonica, of Chinese Neolithic origin. The oldest pottery has simple incised and punctate zoned decoration with parallels in central Thailand, especially in the basal phases at Nong Nor and Khok Phanom Di. From its middle and later occupation phases (1800-1200 B.c.), An Son has produced a number of supine extended burials with finely decorated pottery grave goods that carry some unique forms, especially vessels with wavy or serrated rims. The An Son burials represent a Neolithic population that expressed a mixture of both indigenous Hoabinhian and more northerly (probably Neolithic southern Chinese) cranial and dental phenotypes, perhaps representing a likely ancestral population for some of the modern Austroasiaticspeaking populations of mainland Southeast Asia. Keywords: Vietnam, Neolithic, human biological history, prehistoric food production, prehistoric pottery. 